\title{
Distribución y abundancia de las aves playeras en planos intermareales del Parque Nacional Natural Sanquianga y la bocana de Iscuandé, Nariño (Colombia), entre 2009 y 2020
}

\section{Distribution and abundance of shorebirds in tidal flats of Sanquianga National Natural Park and the mouth of Iscuandé, Nariño (Colombia), between 2009 and 2020}

\author{
Richard Johnston-González ${ }^{1,2^{*}}$, Diana Eusse-González $z^{2}$ y Natasha Valencia-Martínez ${ }^{3}$ \\ $\begin{array}{lll}\text { (i) } 0000-0002-1365-8261 & \text { (D) } 0000-0001-8845-5904 & \text { (iD) } 0000-0002-7535-3228\end{array}$ \\ 1. Coastal Solutions Fellows Program, Cornell Lab of Ornithology, Ithaca, New York, USA/Instituto de Investigaciones Marinas y Costeras (Invemar), \\ Santa Marta, Colombia/Center for Wildlife Ecology, Simon Fraser University, Vancouver, Canadá. richard.johnston@cornell.edu* \\ 2. Asociación para el Estudio y Conservación de las Aves Acuáticas en Colombia (Calidris), Colombia. deusse@calidris.org.co \\ 3. Grupo de investigación en Ecología de Estuarios y Manglares (Ecomanglares), Universidad del Valle, Cali, Colombia. \\ natasha.valencia@correounivalle.edu.co \\ 4. Autor de correspondencia.
}

\section{RESUMEN}

11 $\%$ de las aves playeras del corredor migratorio del Pacífico americano están disminuyendo y otro $46 \%$ no cuenta con información para estimar su estado poblacional. Para entender la magnitud y las causas de estos cambios, se requiere información de sitios de concentración como la bocana de Iscuandé (IS) y el Parque Nacional Natural Sanquianga (PNNS). Para caracterizar la composición de las comunidades de aves playeras en estos sitios, se analizaron diez años de conteo. A partir de la abundancia proporcional, la prevalencia y la densidad media de cada localidad, se evaluó si existían diferencias entre sitios con diferente influencia marina y del río Patía. IS aportó el $63 \%$ de la abundancia promedio, siendo el $80 \%$ aves playeras pequeñas. En PNNS, la abundancia se repartió 40-60 $\%$ entre aves grandes y pequeñas, y la contribución de cada bocana fue proporcional al área muestreada. Estos resultados muestran que los dos sitios tienen comunidades diferentes de aves playeras. Esta heterogeneidad espacial tiene importantes implicaciones ecológicas y de conservación. El recambio en la composición taxonómica y por grupos de tamaño de aves playeras sugiere diferencias en el hábitat intermareal y en los organismos que lo habitan, lo que ofrece alternativas para la conservación de diferentes especies.

PALABRAS CLAVE: aves playeras, planos intermareales, variación espacial, Pacífico colombiano

\section{ABSTRACT}

11

$\%$ of shorebirds using the American Pacific Flyway are declining and an additional $46 \%$ have no information to estimate their population status. To understand the magnitude of these changes and their causes, baseline information is required especially at sites of concentration like the mouth of Iscuandé River (IS) and the Sanquianga National Natural Park (SNNP). To characterize the composition of shorebird communities there, ten years of standardized counts were analyzed. Using proportional abundance, prevalence and mean density of each location, it was evaluated differences between sites with a different marine influence of the Patía River. IS contributed to $63 \%$ of the average abundance in the study area, where $80 \%$ were small shorebirds. Shorebird abundance in SNNP was 40-60 \% among large and small birds, and the contribution of each mouth was proportional to the area sampled. These results show that IS and SNNP host different communities of shorebirds. This spatial heterogeneity has important ecological and conservation implications. The change in their taxonomic and size group composition suggests important differences in intertidal habitat and the organisms who inhabit it and also offers alternatives for the conservation of different assemblages of species.

.KEY WORDS: shorebirds, tidal flats, spatial variation, Colombian Pacific

DOI: https://doi.org/10.25268/bimc.invemar.2020.49.SuplEsp.1094

Publicado por INVEMAR

Published by INVEMAR

Este es un manuscrito de acceso abierto bajo la licencia CC

Reconocimiento-No Comercial-Compartir Igual 


\section{INTRODUCCIÓN}

El norte de la costa de Nariño es reconocido como un sitio de gran riqueza de aves (Calderón-Leytón et al., 2011) y alberga dos áreas reconocidas por su importancia para este grupo. El Parque Nacional Natural Sanquianga (PNNS), un área importante para la conservación de las aves (AICA), y la bocana de Iscuandé (IS), una reserva de aves playeras de la red hemisférica de reservas (RHRAP), son sitios de importancia para la conservación de las aves playeras en la ruta migratoria del Pacífico americano (Senner et al., 2017) y presentan la mayor concentración de aves playeras no reproductivas en Colombia (Johnston-González y EusseGonzález, 2009a). Las aves playeras son aves acuáticas que dependen de humedales en algún momento de su ciclo de vida (Ruiz-Guerra, 2013). Son un componente faunístico muy importante en la región de manglares del norte de Nariño (Calderón-Leytón et al., 2011), donde se han registrado 34 especies, 32 de ellas migratorias (Ruiz-Guerra, 2011). Para el área de estudio se citan alrededor de 10000 aves playeras en un sólo evento de conteo en el PNNS y se estima una población de cerca de 50000 individuos en IS (Asociación Calidris, 2009; Johnston-González et al., 2010; Zamudio et al., 2013; Asociación Calidris y PNN Sanquianga, datos sin publicar). Estas grandes concentraciones corresponden a porcentajes significativos (entre 1 y $10 \%$ ) de las poblaciones biogeográficas de al menos cuatro especies, Actitis macularius, Numenius phaeopus, Charadrius wilsonia y Pluvialis squatarola (Ruiz-Guerra et al., 2007; Johnston-González y Eusse-González, 2009a, 2009b).

A pesar de su importancia, la zona se enfrenta a diversas amenazas. La dinámica del estuario-delta del río Patía-Sanquianga se ha modificado en los últimos 40 años como consecuencia del aumento en los caudales, la sedimentación en los cauces, los efectos de maremotos, el fenómeno de El Niño y el aumento en el nivel del mar. Particularmente, el desvío del río Patía en 1973 generó procesos acelerados de erosión y sedimentación en la línea de costa, alteraciones en los ecosistemas estuarinos, incursión de agua dulce y sedimento en el sistema, aumentando la extensión de los planos intermareales (Restrepo y Cantera, 2011). Se conocen algunos efectos de este "colapso ambiental" (Parra y Restrepo, 2014), pero se desconocen los impactos sobre la biodiversidad asociada con los planos intermareales, en particular sobre las aves playeras.

Debido a la situación ambiental que enfrenta la región, en el Plan de Manejo del Parque Nacional Natural Sanquianga 2018-2023, los planos intermareales fueron

\section{INTRODUCTION}

The north of the coast of Nariño is recognized as a site of great bird richness (Calderón-Leytón et al., 2011) and is home to two areas recognized for their importance for this group. The Sanquianga National Natural Park (SNNP), an important area for the conservation of birds (AICA), and the mouth of Iscuandé (IS), a shorebird reserve of the Western Hemisphere Shorebird Reserve Network (WHSRN), are sites of importance for the conservation of shorebirds in the American Pacific flyway (Senner et al., 2017) and harbor the highest concentration of non-breeding shorebirds in Colombia (Johnston-González and EusseGonzález, 2009a). Shorebirds are waterbirds that depend on wetlands at some point in their life cycle (Ruiz-Guerra, 2013). They are a very important faunal component in the mangrove region of northern Nariño (Calderón-Leytón et al., 2011), where 34 species have been recorded, 32 of them migratory (Ruiz-Guerra, 2011). For the study area, around 10000 shorebirds are reported in a single counting event in the SNNP and a population of about 50000 individuals is estimated in IS (Asociación Calidris, 2009; Johnston-González et al., 2010; Zamudio et al., 2013; Asociación Calidris and Sanquianga NNP (unpublished data). These large concentrations correspond to significant percentages (between 1 and $10 \%$ ) of the biogeographic populations of at least four species, Actitis macularius, Numenius phaeopus, Charadrius wilsonia, and Pluvialis squatarola (Ruiz-Guerra et al., 2007; Johnston-González and Eusse-González, 2009a, 2009b).

Despite its importance, the area faces various threats. The dynamics of the estuary-delta of the PatíaSanquianga River has changed in the last 40 years as a consequence of the increase in the flow, the sedimentation in the channels, the effects of tidal waves, the El Niño phenomenon, and the increase in the level of the sea. In particular, the diversion of the Patía River in 1973 generated accelerated erosion and sedimentation processes on the coastline, alterations in estuarine ecosystems, the incursion of fresh water and sediment in the system, increasing the extension of the tidal flats (Restrepo and Cantera, 2011). Some effects of this "environmental collapse" are known (Parra and Restrepo, 2014), but the impacts on biodiversity associated with tidal flats are unknown, particularly on shorebirds.

Due to the environmental situation facing the region, in the Sanquianga National Natural Park Management Plan 2018-2023, tidal flats were selected as 
seleccionados como Valores Objeto de Conservación (VOC) (PNN Sanquianga, 2017), y se han clasificado como zonas de conservación en el Acuerdo de Zonificación del consejo comunitario Esfuerzo Pescador, al que pertenece la IS (Asociación Calidris y consejo comunitario Esfuerzo Pescador, 2017). Para evaluar el progreso de los acuerdos de manejo del PNNS y de IS, desde 2012 se realizan monitoreos de varios elementos de la biodiversidad, entre ellos las aves playeras en los planos lodosos intermareales.

Estos programas de monitoreo se articularon al proyecto de Aves Playeras Migratorias (MSP) del Pacífico americano, en el que se hace seguimiento a poblaciones de aves playeras en su área de invernada, que abarca sitios desde el sur de Canadá hasta Chile (Reiter et al., 2020). Este programa, que abarca cerca de 100 sitios en los 13 países de la costa americana, contribuye en la identificación de múltiples causas y tasas de cambio local y regional de las aves playeras (Butler et al., 2004). Esto es clave si se considera que $40 \%$ de las poblaciones de aves playeras en el Pacífico americano se encuentran en disminución y $41 \%$ adicional no tienen datos suficientes para estimar su tendencia poblacional (Senner et al., 2017). Entender la magnitud de estos cambios, requiere esfuerzos coordinados que documenten la cantidad y distribución de aves playeras, considerando múltiples escalas espaciales.

En este sentido, las diferencias ecológicas que presentan las especies, deben ser consideradas para entender los patrones espaciales que presentan. Por ejemplo, la distancia migratoria y el tamaño corporal, entre otros factores, han sido evaluados como determinantes de la disminución poblacional de diferentes especies (Thomas et al., 2006). Las aves playeras de tamaño pequeño, como algunas del género Calidris, presentan patrones de distribución contrastantes a los de aves de mayor tamaño (Kauffman et al., 2018). Al menos parte de estas diferencias podrían estar asociadas a repertorios de estrategias antidepredatorias (Lank et al., 2003) que incluyen por ejemplo la selección de hábitats más seguros (Hope, 2018; Johnston-González, 2019) o la disponibilidad localizada de recursos específicos como biopelículas (Jiménez, 2013). Sin embargo, se desconocen los efectos de estas diferencias ecológicas sobre los patrones de distribución de aves de diferente tamaño.

En el presente estudio, se describe la composición de la comunidad de aves playeras en planos intermareales del PNNS y IS en relación con diferencias en el tamaño corporal, además se evalúa la variación espacial al interior de las seis bocanas con influencia diferencial del río Patía-
Conservation Objective Values (COV) (PNN Sanquianga, 2017), and were classified as conservation areas in the Zoning Agreement of the Esfuerzo Pescador Community Council, to which the IS belongs (Asociación Calidris and consejo comunitario Esfuerzo Pescador, 2017). To evaluate the progress of the SNNP and IS management agreements, since 2012 several elements of biodiversity have been monitored, including shorebirds in the tidal flats.

These monitoring programs were articulated with the American Pacific Migratory Shorebird Project (MSP), in which shorebird populations are monitored in their wintering area, which includes sites from southern Canada to Chile (Reiter et al., 2020). This program, which encompasses nearly 100 sites in the 13 countries along the American coast, contributes to the identification of multiple causes and rates of local and regional change in shorebirds (Butler et al., 2004). This is key considering that $11 \%$ of shorebird populations in the American Pacific are in decline and an additional $46 \%$ do not have enough data to estimate their population trend (Senner et al., 2017). Understanding the magnitude of these changes requires coordinated efforts to document the number and distribution of shorebirds, considering multiple spatial scales.

In this sense, the ecological differences that the species present must be considered to understand the spatial patterns that they present. For example, migratory distance and body size, among other factors, have been evaluated as determinants of the population decline of different species (Thomas et al., 2006). Small shorebirds, such as some species of the genus Calidris, present contrasting distribution patterns to larger birds (Kauffman et al., 2018). At least part of these differences could be associated with repertoires of anti-predatory strategies (Lank et al., 2003) that include, for example, the selection of safer habitats (Hope, 2018; Johnston-González, 2019) or the localized availability of specific resources such as biofilms (Jiménez, 2013). However, the effects of these ecological differences on the distribution patterns of birds of different sizes are unknown.

In the present study, the composition of the shorebird community in tidal flats of the SNNP and IS is described in relation to differences in body size; also, the spatial variation within the six mouths with the differential influence of the Patía-Sanquianga River is evaluated. The results of these analyzes will be useful to guide management actions in the territories and to have a baseline of the 
Sanquianga. Los resultados de estos análisis serán útiles para guiar acciones de manejo de los territorios y tener una línea de referencia de la variabilidad natural de la comunidad de aves playeras en relación con cambios ambientales en la zona de estudio.

\section{ÁREA DE ESTUDIO}

La zona de estudio se ubica en el norte de Nariño, en la costa sur del Pacífico colombiano $\left(2^{\circ} 40^{\prime}-2^{\circ} 23^{\prime} \mathrm{N}\right.$ y $78^{\circ} 28^{\prime}-77^{\circ} 55^{\prime} \mathrm{W}$ ) (Figura 1). La región corresponde al sistema Sanquianga, un complejo deltaico en el que confluyen los ríos Patía, Sanquianga, Satinga, Tapaje, Iscuandé y otros cursos menores (Alonso et al., 2008). En este complejo, el bosque de mangle ocupa una franja ancha que alcanza $30 \mathrm{~km}$ en el PNNS por efecto del deltaestuario Patía-Sanquianga y es considerado uno de los más extensos de Suramérica (Restrepo y Kettner, 2012). La zona tiene clima tropical, con temperaturas medias de $26{ }^{\circ} \mathrm{C} \mathrm{y}$ abundantes precipitaciones de entre $3000-3500 \mathrm{~mm}$, ya que está ubicada en una de las regiones más lluviosas de la tierra (Fick y Hijmans, 2017). Presenta un régimen de marea semidiurno que inunda gran parte del área dos veces al día, con una altura de marea mensual que alcanza hasta 4,6 m (IDEAM, 2016).

Los ecosistemas del PNNS y la IS comprenden aproximadamente 94000 ha de hábitats costeros (Asociación Calidris y consejo comunitario Esfuerzo Pescador, 2017; PNN Sanquianga, 2017), con bosques de manglar, estuarios, fondos móviles, playas de arena, planos intermareales (Alonso et al., 2008) y asentamientos humanos.

Este estudio se enfocó en los planos intermareales, el principal hábitat de alimentación para aves playeras (Senner et al., 2017). Estos abarcan más de 12000 ha en la costa norte de Nariño (IDEAM et al., 2007; Murray et. al., 2019). Son reconocidos como uno de los ecosistemas más importantes de la región, al ofrecer recursos temporales que determinan el comportamiento de las especies asociadas y la oferta de recursos provenientes de los otros ecosistemas (von Prahl y Cantera, 1990; Ruiz, 2004). También resaltan por ser ecosistemas de alta productividad (Murray et al., 2019) y un hábitat importante para la alimentación, refugio y reproducción de aves acuáticas, en especial para aves playeras (Johnston-González y Eusse-González, 2009a). Así mismo son un ecosistema importante para las comunidades humanas, ya que proveen alimento y ayudan a la regulación de la erosión costera de la región (Fundación Natura e Invemar, 2019). natural variability of the shorebird community associated with environmental changes in the study area.

\section{STUDY AREA}

The study area is located in the north of Nariño, on the southern coast of the Colombian Pacific $\left(2^{\circ} 40^{\prime}\right.$ $2^{\circ} 23^{\prime} \mathrm{N}$ and $78^{\circ} 28^{\prime}-77^{\circ} 55^{\prime} \mathrm{W}$ ) (Figure 1). The region corresponds to the Sanquianga system, a delta complex in which the rivers Patía, Sanquianga, Satinga, Tapaje, Iscuandé, and other smaller courses converge (Alonso et al., 2008). In this complex, the mangrove forest occupies a wide strip that reaches $30 \mathrm{~km}$ in the SNNP as a result of the Patía-Sanquianga delta-estuary and is considered one of the most extensive in South America (Restrepo and Kettner, 2012). The area has a tropical climate, with average temperatures of $26{ }^{\circ} \mathrm{C}$ and abundant rainfall of between $3000-3500 \mathrm{~mm}$, as it is located in one of the rainiest regions on earth (Fick and Hijmans, 2017). It has a semi-diurnal tidal regime that floods a large part of the area twice a day, with a monthly tidal height that reaches up to 4.6 m (IDEAM, 2016).

The ecosystems of the SNNP and the IS comprise approximately 94,000 ha of coastal habitats (Asociación Calidris and consejo comunitario Esfuerzo Pescador, 2017; PNN Sanquianga, 2017), with mangrove forests, estuaries, mobile bottoms, sandy beaches, intertidal mud flats (Alonso et al., 2008) and human settlements.

This study focused on tidal flats, the main foraging habitat for shorebirds (Senner et al., 2017). These cover more than 12000 ha on the north of Nariño coast (IDEAM et al., 2007; Murray et. al., 2019). They are recognized as one of the most important ecosystems in the area, by offering temporary resources that determine the behavior of the associated species and the supply of resources from other ecosystems (von Prahl and Cantera, 1990; Ruiz, 2004). They also stand out for being highly productive ecosystems (Murray et al., 2019) and an important habitat for feeding, refuge, and reproduction of waterbirds, especially for shorebirds (Johnston-González and EusseGonzález, 2009a). Likewise, they are an important ecosystem for human communities that provide food and help to regulate coastal erosion in the region (Fundación Natura and Invemar, 2019). 

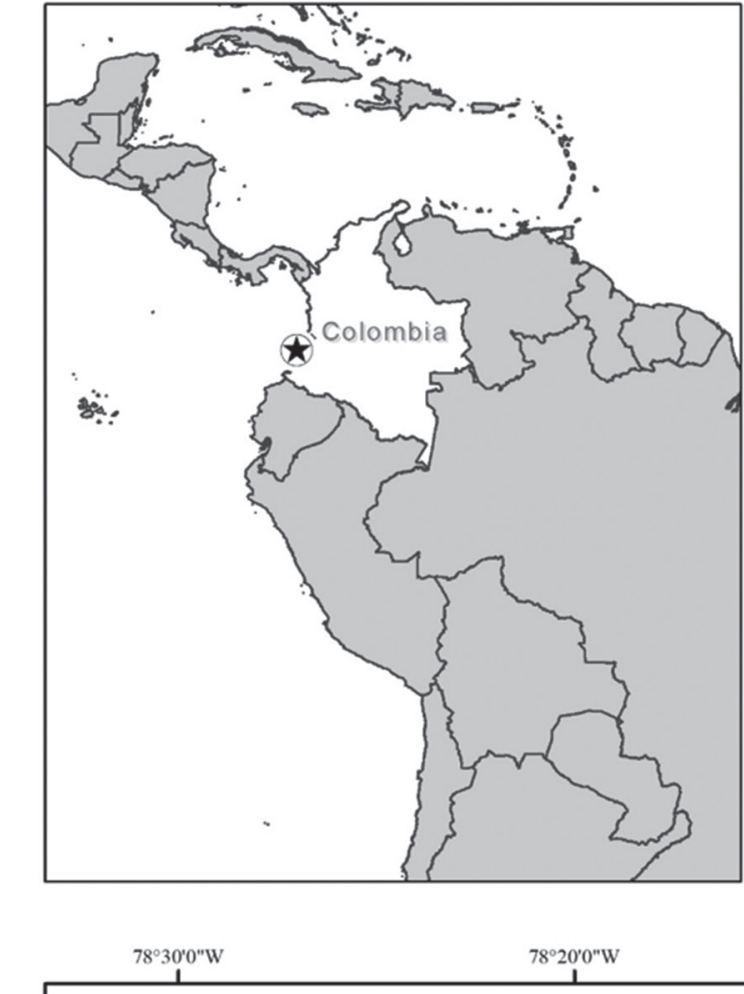

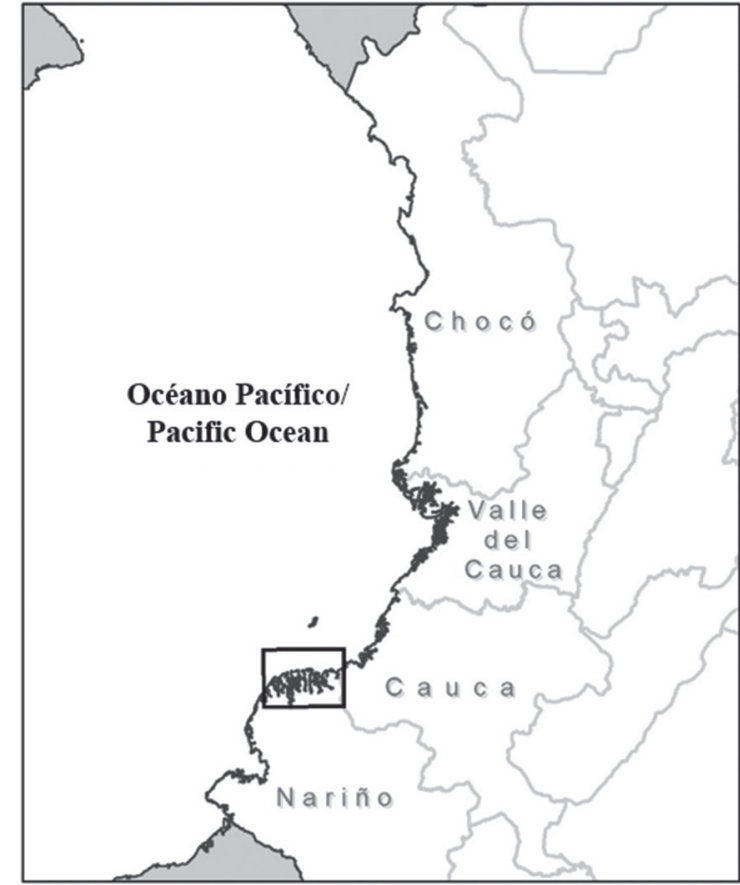

$78^{\circ} 10^{\prime} 0^{\prime \prime W}$

$78^{\circ} 0^{\circ} 0^{\prime \prime} \mathrm{W}$

\section{Océano Pacífico/Pacific Ocean}

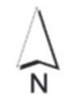

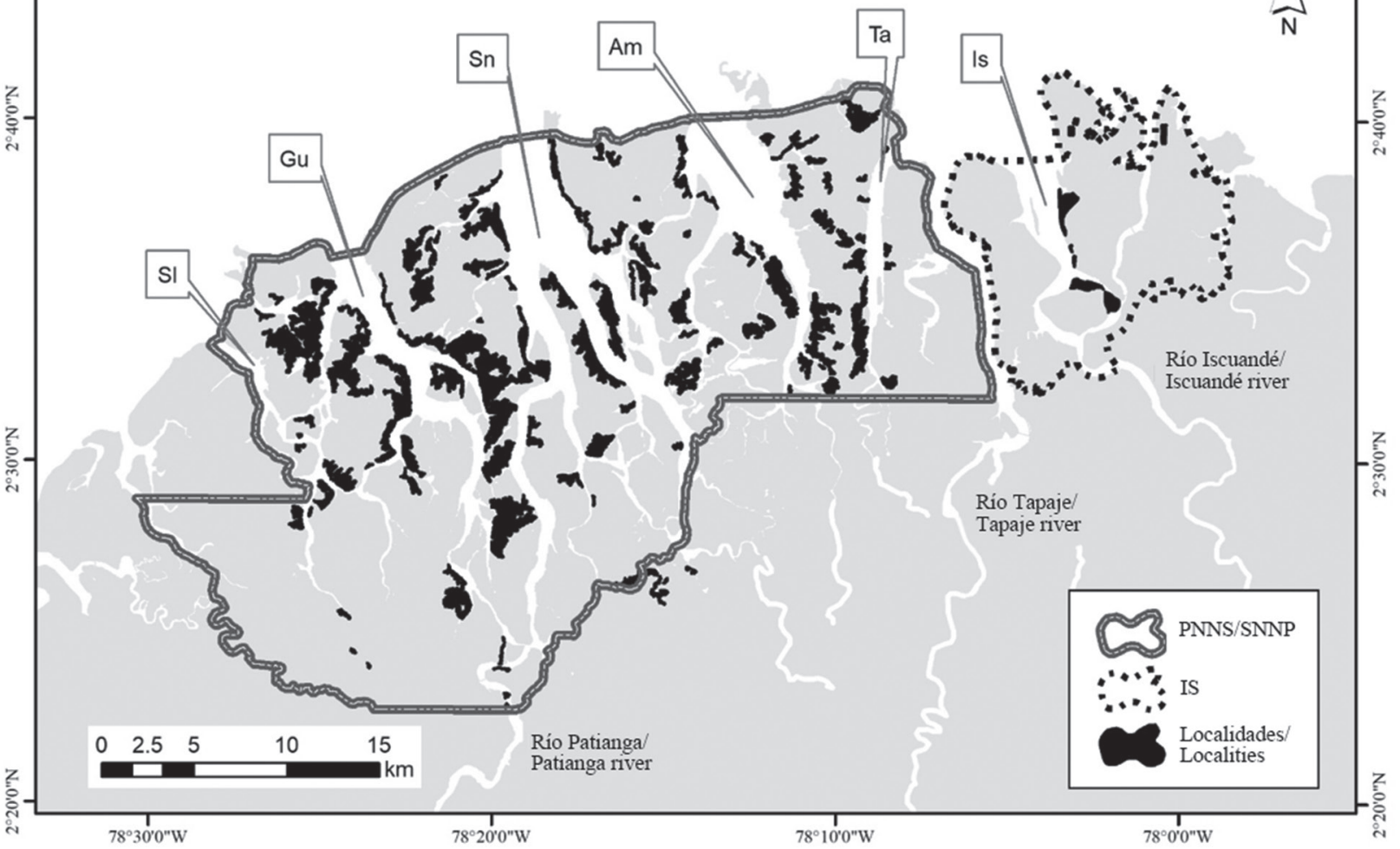

Figura 1. Área de estudio. Ubicación de los planos lodosos intermareales en PNNS y IS en el Pacífico colombiano: S1 = Salango. Gu = Guascama. $\mathrm{Sn}=$ Sanquianga. $\mathrm{Am}=$ Amarales $. \mathrm{Ta}=$ Tapaje. Is $=$ Iscuandé .
Figure 1. Study area. Location of the tidal flats in PNNS and IS in the Colombian Pacific: $\mathrm{Sl}=$ Salango. $\mathrm{Gu}=$ Guascama. $\mathrm{Sn}=$ Sanquianga . $\mathrm{Am}=$ Amarales $. \mathrm{Ta}=$ Tapaje. Is $=$ Iscuandé. 
Para el PNNS se usó el mapa de ecosistemas del área (Unidad Administrativa Especial del Sistema de PNN, 2007), que incluye 946 planos intermareales (polígonos), los cuales ocupan 10190 ha (Alonso et al., 2008) en las cinco bocanas principales del PNNS. Las bocanas del PNNS muestran diferencias en caudal, ancho del delta, tasa de sedimentación en los canales transversales y retroceso de la cuña salina en el estuario fluvial. Estas diferencias entre las bocanas, parecen ser efecto del río Patía-Sanquianga y van desde un nivel medio en la bocana de Salango al occidente, alta en las bocanas de Guascama y Sanquianga y de media a baja en Amarales y Tapaje en el oriente del PNNS (Parra y Restrepo, 2014). Adicionalmente cerca de 2000 ha adicionales de este hábitat se encuentran en la IS, la cual se seleccionó como una sexta bocana. En IS el área de planos intermareales está concentrada en la boca del río, donde se forman islas barreras en constante cambio debido a la erosión intensa por efecto del mar y la sedimentación del río Iscuandé (Posada et al., 2009).

\section{MATERIALES Y MÉTODOS}

Para entender el comportamiento de la comunidad de las aves playeras al interior del PNNS y en IS se delimitó el área de influencia de las seis bocanas en un mapa de ecosistemas de los sitios y se seleccionaron planos intermareales al interior de cada una. Se seleccionaron 155 planos intermareales en el PNNS y 7 en IS, como localidades de muestreo (Figura 1). La selección y distribución de localidades respondió a la disponibilidad de sitios en cada bocana y a la facilidad de acceso (navegabilidad y seguridad). El trabajo de campo se realizó en 2009 y entre 2012 a 2020 para un total de 10 años. Cada localidad se visitó una vez cada año entre el 15 de enero y el 15 de febrero, período en que las poblaciones migratorias de aves playeras se han establecido en sus áreas no reproductivas (Reiter et al., 2020). Cada año se visitaron entre 58 y 96 localidades cubriendo entre 17-30 \% (2485-4258 ha) del hábitat total de la zona de estudio (14 000 ha) (Anexo 1). Los conteos se realizaron desde embarcaciones y sólo dos localidades en IS, los bajos La Cunita y Quiñonez, se hicieron a pie debido a su gran extensión. Los conteos desde embarcaciones se realizaron entre dos a tres horas antes y después de la bajamar, mientras que los conteos a pie se realizaron dos horas después de la pleamar.

En PNNS los conteos se hicieron durante cuatro días consecutivos con pleamares máximas entre las 3:00 y 5:00 h, mientras que en IS se realizaron conteos en dos
The map of ecosystems of the area (Special Administrative Unit of the PNN System, 2007) was used for the SNNP, which reports 946 tidal flats (polygons), which occupy 10190 ha (Alonso et al., 2008) in the five mouths of the SNNP. The mouths of the SNNP show differences in flow, delta width, sedimentation rate in the transverse channels, and retreat of the saline wedge in the river estuary. These differences between the mouths seem to be an effect of the Patía-Sanquianga River and range from a medium level in the Salango mouth to the west, high in the Guascama and Sanquianga mouths, and from medium to low in Amarales and Tapaje in the east of the SNNP (Parra and Restrepo, 2014). Additionally, about 2000 additional ha of this habitat are found in the IS, which was selected as a sixth mouth. In IS, the area of muddy planes is concentrated at the mouth of the river, where barrier islands are formed in constant change due to intense erosion by the effect of the sea and the sedimentation of Iscuandé River (Posada et al., 2009).

\section{MATERIALS AND METHODS}

To understand the behavior of the shorebird community within the SNNP and in IS, the area of influence of the six mouths was delimited on an ecosystem map of the sites and tidal flats were selected within each one. 155 tidal flats were selected in the SNNP and 7 in IS, as sampling locations (Figure 1). The selection and distribution of locations responded to the availability of sites in each entrance and ease of access (navigability and security). The fieldwork was carried out in 2009 and between 2012 and 2020 for a total of 10 years. Each locality was visited once each year between January 15 and February 15, a period in which migratory shorebird populations have become established in their non-breeding areas (Reiter et al., 2020). Each year between 58 and 96 localities were visited, covering between 17-30 \% (2485$4258 \mathrm{ha}$ ) of the total habitat of the study area (14000 ha) (Appendix 1). The counts were made from boats and only two localities in IS, the La Cunita and Quiñonez, were made on foot due to their great extension. Counts from boats were made two to three hours before and after low tide, while counts on foot were made two hours after high tide.

In SNNP, the counts were made during four consecutive days with maximum high tides between 3:00 and 5:00 h, while in IS, counts were made on two consecutive days with maximum high tides between 
días consecutivos con pleamares máximas entre las 5:00 y 6:00 h. La selección del horario y el tiempo mareal buscó que la exposición de los planos intermareales sea la máxima durante el conteo de aves playeras, pero que permita la navegación entre los esteros. En cada localidad se realizó un conteo e identificación de las aves playeras y se registraron características de cada localidad, cómo el estado de inundación, y proporción del hábitat visible. Otras variables de hábitat (presencia y altura de vegetación) y clima (nubosidad y precipitación), fueron registradas siguiendo las recomendaciones del proyecto MSP (Reiter et al., 2020).

Para disminuir los sesgos asociados a la identificación y conteo de grandes bandadas sólo se contaron aves hasta $200 \mathrm{~m}$ de distancia de los observadores. Para bandadas de varios miles de individuos se hizo necesario la estimación (decenas, cientos, miles) y el conteo repetido (a veces con varios observadores) hasta lograr un consenso. En el caso de bandadas mixtas se hizo una primera estimación del tamaño de la bandada y luego de los porcentajes por especies de varios grupos seleccionados en el campo del telescopio o binocular. Especies similares como Calidris mauri y $C$. pusilla pueden distinguirse con una combinación de marcas de campo, en especial el tamaño del pico (Pyle, 2008). Sin embargo, en las situaciones mencionadas (bandadas grandes y mixtas) no siempre es fácil separar las especies, por lo que se decidió unirlas para los análisis.

Composición de la comunidad de aves. Para caracterizar la composición taxonómica de la comunidad de aves playeras en PNNS y IS se evaluó la frecuencia como el número de localidades con registros/total de localidades y el número de registros/total de registros de todas las especies y abundancia de cada especie como el valor máximo anual en toda el área de estudio dividido por el total acumulado de todas las especies. Se compararon las proporciones de familias y de grupos de especies por tamaño con estadística descriptiva.

Variación espacial de la frecuencia. Para identificar si existen diferencias en la distribución espacial de las especies de aves playeras se comparó la probabilidad de registrar cada especie entre las seis bocanas que conforman el área de estudio. Para cada especie se construyó un modelo lineal generalizado mixto(GLMM) con distribución binomial. Este modelo usó el número de visitas con registros de la especie para estimar la probabilidad de presencia (variable respuesta) en función de la bocana donde se encuentra (variable explicativa). Se usó la localidad de muestreo como una variable aleatoria anidada dentro de cada bocana. Se
5:00 and 6:00 h. The selection of the time and tidal time sought to ensure that the exposure of the tidal flats is the maximum during the shorebird count, but that it allows navigation between the estuaries. In each locality, a count and identification of shorebirds were carried out and characteristics of each locality were recorded, such as the state of flooding, and the proportion of the visible habitat. Other habitat variables (presence and height of vegetation) and climate (cloudiness and precipitation) were recorded following the recommendations of the MSP project (Reiter et al., 2020).

To reduce biases associated with the identification and counting of large flocks, only birds up to $200 \mathrm{~m}$ away from the observers were counted. For flocks of several thousand individuals, estimation (tens, hundreds, thousands) and repeated counting (sometimes with several observers) was necessary until consensus was reached. In the case of mixed flocks, a first estimate was made of the size of the flock and then of the percentages by species of several groups selected in the telescope or binocular field. Similar species such as Calidris mauri and $C$. pusilla can be distinguished with a combination of field markings, especially bill size (Pyle, 2008). However, in the mentioned situations (large and mixed flocks) it is not always easy to separate the species, so it was decided to unite them for the analyzes.

Composition of the bird community. To characterize the taxonomic composition of the shorebird community in SNNP and IS, the frequency was evaluated as the number of locations with records/total locations and the number of records/total records of all species and abundance of each species as the maximum annual value in the entire study area divided by the accumulated total of all species. The proportions of families and groups of species by size were compared using descriptive statistics.

Spatial variation of frequency. To identify if there are differences in the spatial distribution of shorebird species, the probability of registering each species among the six mouths that form the study area were compared. For each species, a mixed generalized linear model (GLMM) with binomial distribution was fitted. This model used the number of visits with records of the species to estimate the probability of presence (response variable) as a function of the river mouth (explanatory variable). The sampling location was used as a random variable nested within each mouth. The fit of the model was evaluated with the quotient of its statistical deviation divided by the statistical 
evaluó el ajuste del modelo con el cociente de su desviación estadística dividido por la desviación estadística del modelo nulo (Ho: la probabilidad media de registrar la especie no difiere entre bocanas). Para determinar la significancia de la prueba se usó el estadístico $\mathrm{Z}$ y el test Wald chi-test, y se hicieron pruebas posteriores de Tukey para determinar entre cuáles pares de bocanas existe evidencia de diferencia de la probabilidad de presencia de cada especie.

Variación espacial de la densidad. Se evaluó la variación espacial en la abundancia mediante un modelo lineal con la densidad (individuos/ha) como variable respuesta y la bocana como variable explicativa. Por la escasez de datos para Salango, se decidió no incluir esta bocana en el análisis. Se hicieron pruebas posteriores de Tukey para determinar entre cuáles pares de bocanas existe evidencia de diferencia de la densidad de cada especie. Se usó el estadístico F con un nivel de significancia de $\mathrm{P}=0,05$. Los modelos para frecuencia y densidad fueron implementados con el paquete lsmeans (Lenth, 2016) en el programa estadístico R (R Core Team, 2020).

\section{RESULTADOS}

Las aves playeras estuvieron presentes en 158 de 162 de las localidades visitadas en el conteo de IS y PNNS entre 2009 y 2020. Scolopacidae fue la familia más frecuente, con al menos un registro en todas las localidades con aves playeras, mientras Charadriidae fue registrada en poco más de la mitad de las localidades y Haematopodidae en solo cuatro (Figura 2A). Las especies grandes contribuyeron con $55 \%$ de los registros de aves playeras acumulados en 10 años de conteo (Anexo 2). Este aporte fue mayor en la familia Haematopodidae y Scolopacidae, que en Charadriidae (Figura 2B, Anexo 2). Tres de las cuatro especies más comunes fueron aves grandes (N. phaeopus, T. semipalmata y T. melanoleuca) y en su conjunto contribuyeron con $42 \%$ de todos los registros acumulados en 10 años de conteo (Figura 2C, Anexo 2). Numenius phaeopus y Actitis macularius tienen la distribución más amplia (Figura 2C), presentes en $95 \%$ de las localidades visitadas mientras que C. mauri y C. pusilla contribuyeron con dos terceras partes de la abundancia total anual (Figura 2D). En conjunto estos resultados muestran que las aves playeras son ubicuas en el paisaje costero de IS y PNNS, ya que ocupan casi todas las localidades de hábitat intermareal. Adicionalmente las aves grandes tienen una mayor distribución (más localidades y registros acumulados), mientras unas pocas especies de aves pequeñas dominan numéricamente. deviation of the null model (Ho: the mean probability of registering the species does not differ between mouths). To determine the significance of the test, the $\mathrm{Z}$ statistic and the Wald chi-test were used, and subsequent Tukey tests were performed to determine between which pairs of mouths there is evidence of a difference in the probability of the presence of each species.

Spatial variation of density. The spatial variation in abundance was evaluated using a linear model with density (individuals/ha) as the response variable and the mouth as the explanatory variable. Due to the scarcity of data for Salango, it was decided not to include this mouth in the analysis. Subsequent Tukey tests were performed to determine between which pairs of mouths there is evidence of a difference in the density of each species. The F statistic was used with a level of significance of $\mathrm{P}=0.05$. The models for frequency and density were implemented with the lsmeans package (Lenth, 2016) in the R statistical program (R Core Team, 2020).

\section{RESULTS}

Shorebirds were present in 158 out of 162 of the localities visited in the IS and SNNP count between 2009 and 2020. Scolopacidae was the most frequent family, with at least one record in all localities with shorebirds, while Charadriidae was recorded in little more than half of the localities and Haematopodidae in only four (Figure 2A). Large species contributed $55 \%$ of the accumulated shorebird records in 10 counting years (Appendix 2). This contribution was greater in the families Haematopodidae and Scolopacidae than in Charadriidae (Figure 2B, Appendix 2). Three of the four most common species were large birds ( $N$. phaeopus, T. semipalmata and $T$. melanoleuca) and together they contributed $42 \%$ of all records accumulated in 10 years (Figure 2C, Appendix 2). Numenius phaeopus and Actitis macularius have the widest distribution (Figure 2C), present in $95 \%$ of the localities visited while $C$. mauri and C. pusilla contributed two-thirds of the total annual abundance (Figure 2D). Together these results show that shorebirds are ubiquitous in the IS and SNNP coastal landscape since they occupy almost all intertidal habitat locations. Additionally, large birds have a greater distribution (more locations and accumulated records), while a few small bird species dominate numerically. 
Al interior del PNNS el aporte de la abundancia fue proporcional a su área muestreada, contrario a lo observado en la bocana de Iscuandé, que aportó un promedio de $63 \%$ de la abundancia anual, 21 veces más de lo esperado por su área muestreada, que es apenas 3,4\% del total en el área de estudio (Figura 3). Las bocanas Sanquianga y Guascama,
Within the SNNP the contribution of abundance was proportional to its sampled area, contrary to what was observed in the mouth of Iscuandé, which contributed an average of $63 \%$ of the annual abundance, 21 times more than expected for its sampled area, which is only $3.4 \%$ of the total in the study area (Figure 3). The Sanquianga and

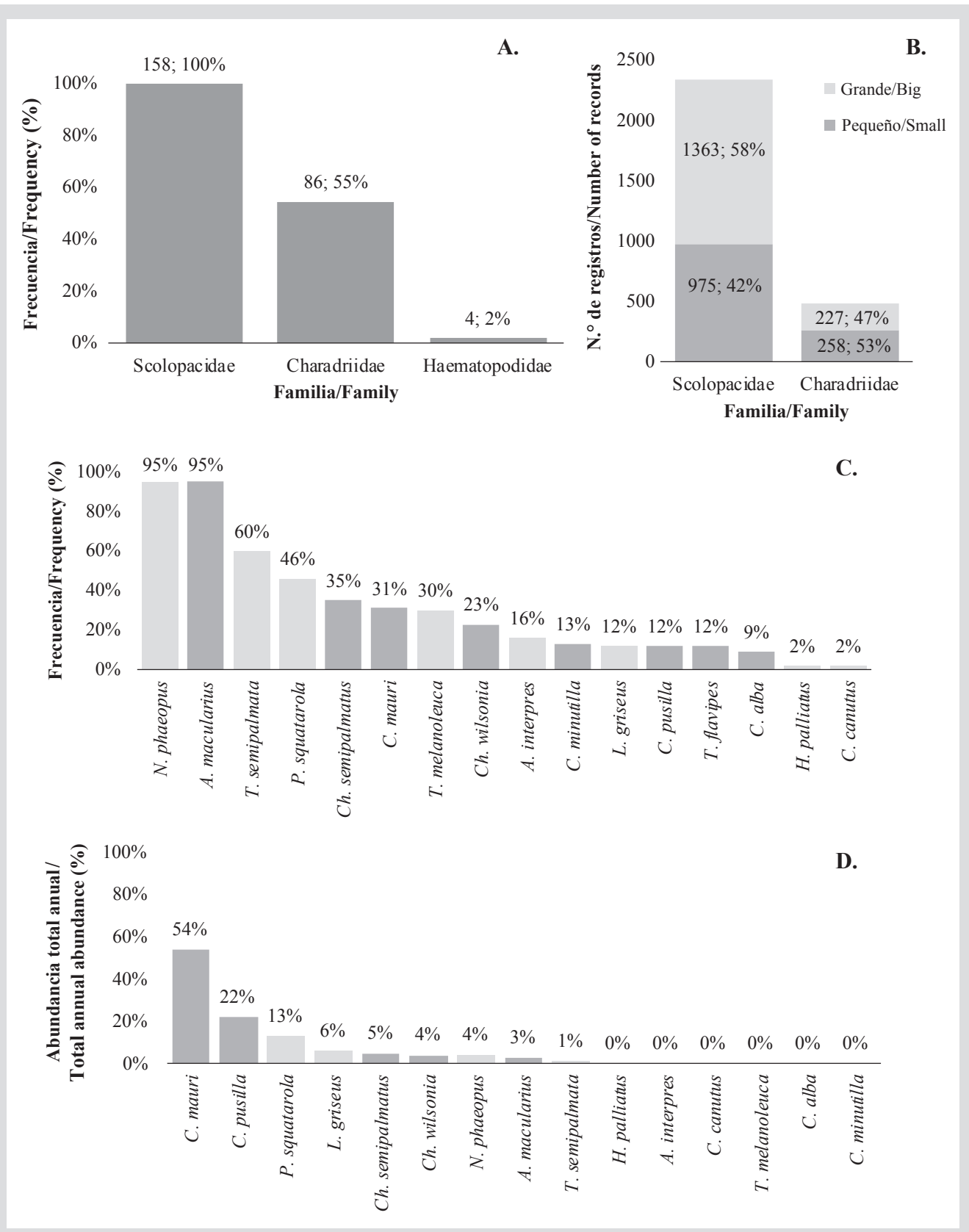

Figura 2. Frecuencia (proporción de localidades con registros), registros y abundancia de aves playeras por familia en PNNS y IS. A) Frecuencia por familia. B) Registros por familia y categoría de tamaño (H. palliatus, única especie de Haematopodidae, solo cuenta con 25 registros y no se muestra en la figura). C) Frecuencia (\%) por especie. D) Abundancia total anual máxima. En B), C) y D) las especies pequeñas se representan con gris oscuro y las grandes con gris más claro. Ver Anexo 2 para valores absolutos y detalles adicionales.
Figure 2. Frequency (proportion of localities with records), records, and abundance of shorebirds by family in PNNS and IS. A) Frequency by family. B) Records by family and size category (H. palliatus only species of Haematopodidae, only has 25 records and is not shown in the Figure). C) Frequency (\%) by species. D) Maximum annual total abundance. In B), C) and D) the small species are represented with dark gray and the large ones with the lighter gray. See Annex 2 for absolute values and additional details. 


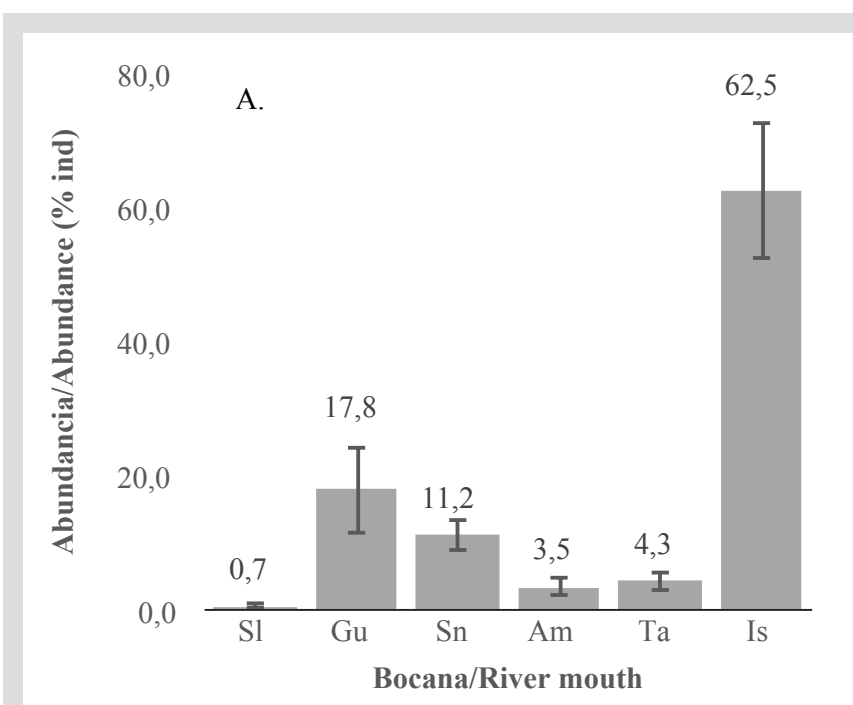

Figura 3. Contribución de cada bocana a A) abundancia total de aves playeras y B) área muestreada durante 10 años de conteo. (Las barras indican el promedio y las líneas un error estándar). Los datos para cada año se encuentran en el Anexo 3. Bocanas: Sl= Salango. Gu= Guascama. $\mathrm{Sn}=$ Sanquianga. $\mathrm{Am}=$ Amarales. Ta $=$ Tapaje. Is $=$ Iscuandé.
80,0

B.

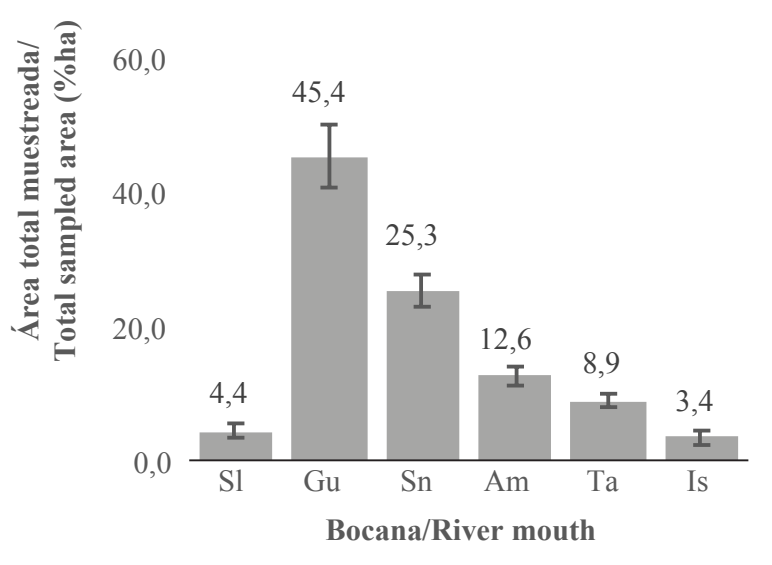

Figure 3. Contribution of each river mouth to A) Total abundance of shorebirds and B) Area sampled during 10 counting years. (The bars indicate the average and the lines a standard error). The data for each year are found in Annex 3. Mouths: $\mathrm{Sl}=$ Salango. $\mathrm{Gu}=$ Guascama. $\mathrm{Sn}=$ Sanquianga. $\mathrm{Am}=$ Amarales. $\mathrm{Ta}=$ Tapaje. Is $=$ Iscuandé. contribuyeron con un promedio de $29 \%$ de la abundancia anual y $70 \%$ del área muestreada, mientras las bocanas restantes (Amarales, Tapaje y Salango) aportaron $9 \%$ restante con $26 \%$ del área muestreada (Anexo 3).

Se encontraron diferencias en la composición por categorías de tamaño entre IS y PNNS. Dentro de PNNS la composición entre aves grandes y pequeñas fue similar variando proporcionalmente entre 40 y $50 \%$, mientras que en IS predominaron las aves pequeñas sobre las grandes con $81 \%$ de la abundancia (Figura 4A). También en IS, $87 \%$ la abundancia de playeras grandes fue contribuida por P. squatarola y L. griseus (Figura 4B), mientras que $90 \%$ de aves pequeñas fue aportado por C. mauri/pusilla (Figura 4C). Por su parte, en PNNS N. phaeopus contribuyó con $65 \%$ de la abundancia de aves grandes y A. macularius con $55 \%$ de aves pequeñas. Adicionalmente, la composición de las bocanas Guascama y Sanquianga difiere de las otras bocanas en PNNS, con una mayor de abundancia de T. semipalmata y C.mauri/pusilla. En conjunto estos resultados muestran que la composición, medida como el aporte porcentual a la abundancia total, fue muy diferente entre IS y PNNS y que en este último las bocanas con mayor influencia del Patía (Guascama y Sanquianga) presentan una composición ligeramente diferente del resto del parque.

Seis de ocho especies presentaron mayor probabilidad de presencia en la bocana de Iscuandé
Guascama mouths contributed an average of $29 \%$ of the annual abundance and $70 \%$ of the sampled area, while the remaining mouths (Amarales, Tapaje, and Salango) contributed the remaining $9 \%$ with $26 \%$ of the sampled area (Appendix 3).

Differences were found in the composition by size categories between IS and SNNP. Within SNNP, the composition between large and small birds was similar, varying proportionally between 40 and $50 \%$, while in IS, small birds predominated over large birds with $81 \%$ of the abundance (Figure 4A). Also in IS $87 \%$ of the abundance of large shorebirds was contributed by $P$. squatarola and L. griseus (Figure 4B), while $90 \%$ of small birds were contributed by C. mauri/pusilla (Figure 4C). On the other hand, in SNNP N. phaeopus contributed $65 \%$ of the abundance of large birds and A. macularius 55\% of small birds. Additionally, the composition of the Guascama and Sanquianga mouths differs from the other mouths in SNNP, with a higher abundance of $T$. semipalmata and C. mauri/pusilla. Together these results show that the composition, measured as the percentage contribution to the total abundance, was very different between IS and SNNP and that in the latter the mouths with the greatest influence from Patía (Guascama and Sanquianga) present a slightly different composition from the rest of the park.

Six out of eight species had a higher probability of presence in the Iscuandé mouth (Figure 5), $N$. 


\section{A. General}

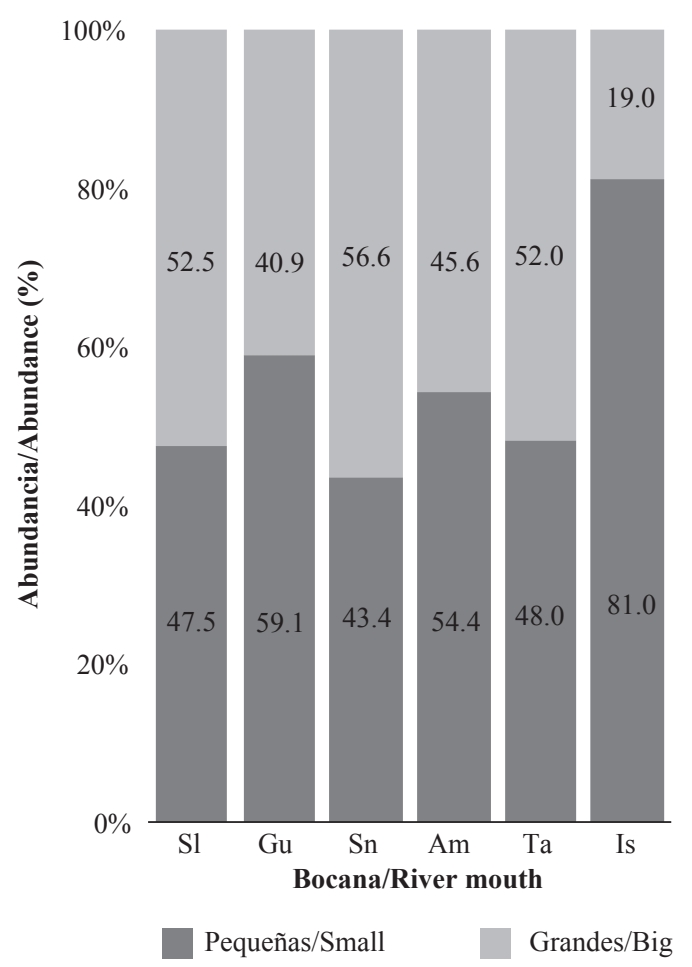

Figura 4. Proporción de la abundancia de especies de aves playeras comunes por A) categoría de tamaño y por especie dentro de cada categoría (B y C). Los colores más oscuros indican las especies menos abundantes. $\mathrm{Sl}=$ Salango. $\mathrm{Gu}=$ Guascama. $\mathrm{Sn}=$ Sanquianga. $\mathrm{Am}=$ Amarales. Ta $=$ Tapaje. Is $=$ Iscuandé.
B. Especies grandes/Big species

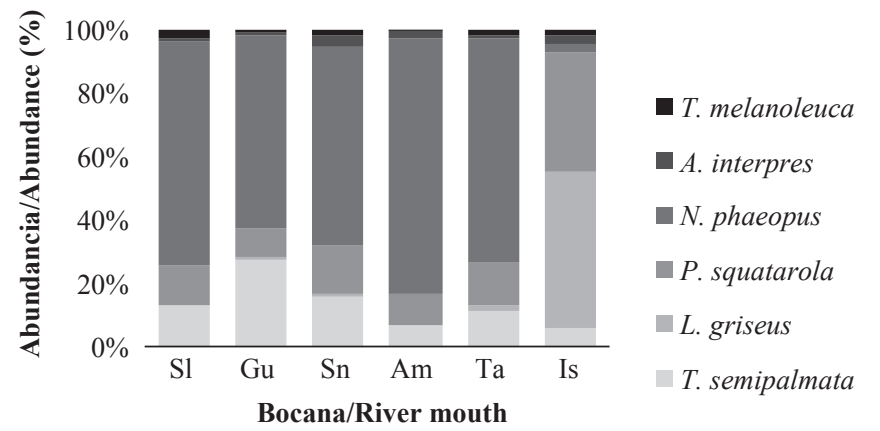

C. Especies pequeñas/Small species

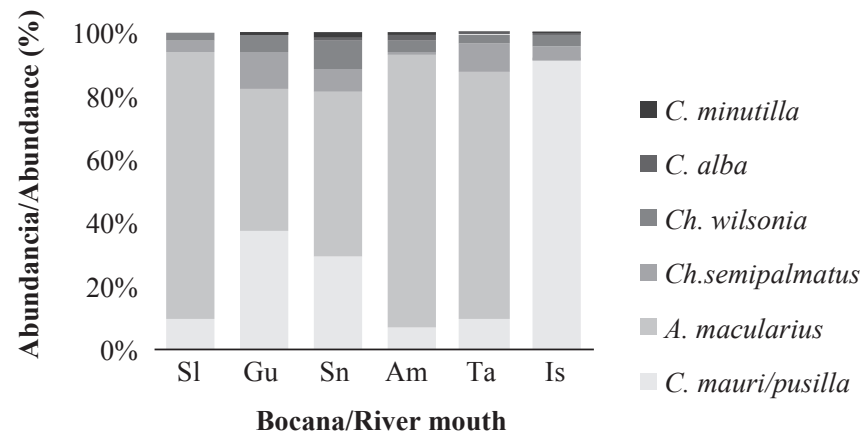

Figure 4. Proportion of abundance of common shorebird species by $\mathbf{A})$ Size category and by species within each category (B and $\mathbf{C})$. The darker colors indicate the less abundant species. $\mathrm{Sl}=$ Salango. $\mathrm{Gu}=$ Guascama. $\mathrm{Sn}=$ Sanquianga $. \mathrm{Am}=$ Amarales. $\mathrm{Ta}=$ Tapaje. Is $=$ Iscuandé .
(Figura 5), N. phaeopus presentó una probabilidad similar en todas las bocanas y $A$. macularia una probabilidad menor en las bocanas Salango e Iscuandé. Al interior del PNNS las seis especies (T. semipalmata, T. melanoleuca, P. squatorola, C. mauri/pusilla, Ch. wilsonia y Ch. semipalmatus) muestran diferencias entre las bocanas. En general, en las bocanas de Guascama y Sanquianga la probabilidad de presencia es mayor para las seis especies, aunque solo para $T$. semipalmata la diferencia entre estas bocanas es significativa. Charadrius wilsonia tienen probabilidad de presencia significativamente menor al promedio. En la Tabla 1 se muestran los valores promedio de la probabilidad de presencia con su error estándar de las ocho especies.

En cuanto a densidad (Figura 6, Tabla 2), seis especies (T. semipalmata, T. melanoleuca, P. squatorola, C. mauri/pusilla, Ch. wilsonia y Ch. semipalmatus) tienen una densidad significativamente más alta en la bocana de Iscuandé, mientras que en las bocanas del PNNS la densidad phaeopus had a similar probability in all the mouths, and A. macularia a lower probability in the Salango and mouth of Iscuandé. Within the SNNP the six species (T. semipalmata, T. melanoleuca, P. squatorola, C. mauri/ pusilla, Ch. Wilsonia, and Ch. Semipalmatus) show differences between the mouths. In general, in the Guascama and Sanquianga mouths the probability of presence is higher for the six species, although only for T. semipalmata the difference between these mouths is significant. Charadrius wilsonia has a significantly lower than average probability of presence. Table 1 shows the average values of the probability of presence with its standard error of the eight species.

Regarding density (Figure 6, Table 2), six species (T. semipalmata, T. melanoleuca, P. squatorola, C. mauri/ pusilla, Ch. wilsonia, and Ch. semipalmatus) have a significantly higher density in the mouth of Iscuandé, while in the mouths of the SNNP the density is lower than average. Numenius phaeopus and A. macularius do not 
es menor al promedio. Numenius phaeopus y A. macularius no presentan diferencias significativas en las seis bocanas estudiadas, aunque esta última sí muestra una densidad más alta que el promedio en la bocana de Tapaje. show significant differences in the six mouths studied, although the latter does show a higher density than the average in the Tapaje mouth.

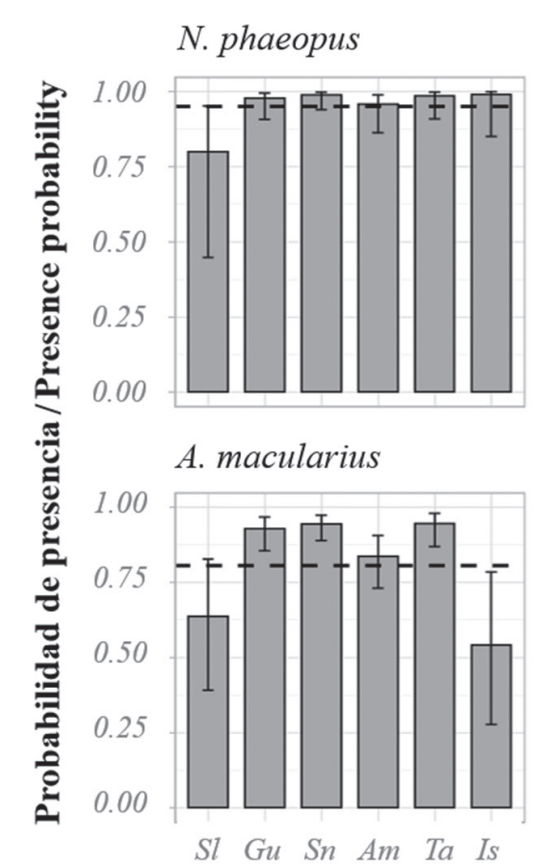

\section{T. semipalmata}

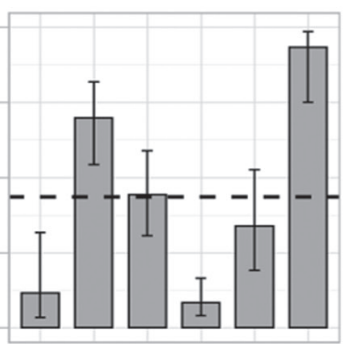

C. mauri/pusilla

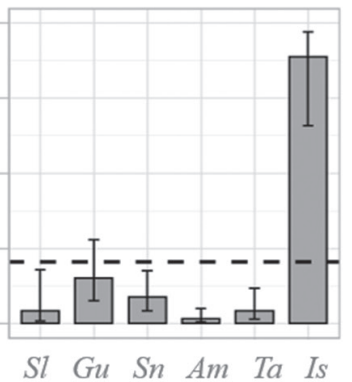

T. melanoleuca

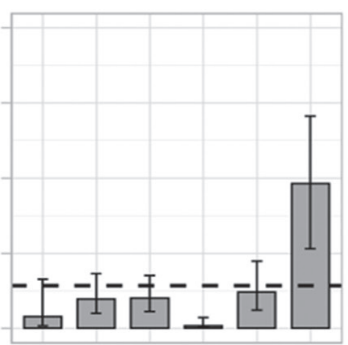

Ch. wilsonia

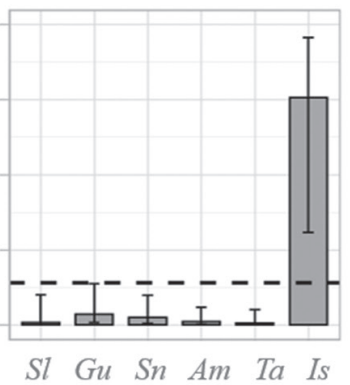

P. squatarola

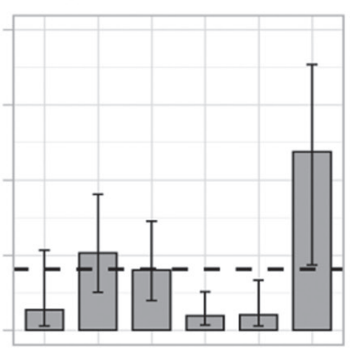

Ch. semipalmatus

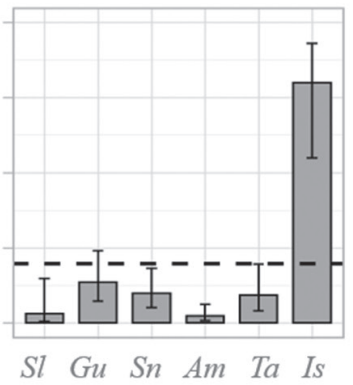

\section{Bocana/River mouth}

Figura 5. Variación espacial en la probabilidad de presencia de ocho especies de aves playeras en cinco bocanas del PNNS ( $\mathrm{Sl}=$ Salango, $\mathrm{Gu}=$ Guascama, $\mathrm{Sn}=$ Sanquianga, $\mathrm{Am}=$ Amarales y $\mathrm{Ta}=$ Tapaje) $\mathrm{e}$ IS (Iscuandé). Los puntos representan el promedio de cada bocana y las barras los intervalos de confianza de $95 \%$. La línea punteada y el número debajo de cada especie es el promedio global de probabilidad de presencia para toda el área de estudio.
Figure 5. Spatial variation in the probability of the presence of eight species of shorebirds in five mouths of the PNNS ( $\mathrm{Sl}=$ Salango, $\mathrm{Gu}=$ Guascama, $\mathrm{Sn}=$ Sanquianga, $\mathrm{Am}=$ Amarales, and $\mathrm{Ta}=$ Tapaje) and IS (Iscuandé). The points represent the average of each mouth and the bars the $95 \%$ confidence intervals. The dotted line and the number below each species is the global average probability of occurrence for the entire study area.
Tabla 1. Probabilidad promedio y error estándar (SE) en la presencia de ocho especies de aves playeras comunes en cinco bocanas del Parque Nacional Natural Sanquianga $(\mathrm{S} 1=$ Salango, $\mathrm{Gu}=$ Guascama, $\mathrm{Sn}=$ Sanquianga, $\mathrm{Am}=$ Amarales y $\mathrm{Ta}=$ Tapaje) y la bocana de Iscuandé (Is).
Table 1. Average probability and standard error (SE) of the presence of eight species of common shorebirds in five mouths of the Sanquianga National Natural Park $(\mathrm{Sl}=$ Salango, $\mathrm{Gu}=$ Guascama, $\mathrm{Sn}=$ Sanquianga, $\mathrm{Am}=$ Amarales, and $\mathrm{Ta}=$ Tapaje) and the mouth of Iscuandé (Is).

\begin{tabular}{|l|c|c|c|c|c|c|}
\hline \multicolumn{1}{|c|}{ Spp/Bocana } & SI & Gu & Sn & Am & Ta & Is \\
\hline N. phaeopus & $0.8(0.13)$ & $0.98(0.02)$ & $0.99(0.01)$ & $0.96(0.03)$ & $0.99(0.01)$ & $0.99(0.01)$ \\
\hline T. semipalmata & $0.12(0.07)$ & $0.7(0.07)$ & $0.44(0.07)$ & $0.08(0.03)$ & $0.34(0.09)$ & $0.93(0.05)$ \\
\hline T. melanoleuca & $0.04(0.03)$ & $0.1(0.03)$ & $0.1(0.03)$ & $0.01(0.01)$ & $0.12(0.04)$ & $0.48(0.12)$ \\
\hline P. squatarola & $0.07(0.05)$ & $0.26(0.08)$ & $0.2(0.07)$ & $0.05(0.02)$ & $0.05(0.03)$ & $0.59(0.2)$ \\
\hline A. macularius & $0.64(0.12)$ & $0.93(0.03)$ & $0.94(0.02)$ & $0.84(0.04)$ & $0.95(0.03)$ & $0.54(0.14)$ \\
\hline C. mauri/pusilla & $0.04(0.03)$ & $0.15(0.05)$ & $0.09(0.03)$ & $0.02(0.01)$ & $0.04(0.02)$ & $0.89(0.07)$ \\
\hline Ch. wilsonia & $0.01(0.01)$ & $0.04(0.03)$ & $0.02(0.02)$ & $0.01(0.01)$ & $0.01(0.01)$ & $0.76(0.18)$ \\
\hline Ch. semipalmatus & $0.03(0.03)$ & $0.14(0.04)$ & $0.1(0.03)$ & $0.02(0.01)$ & $0.09(0.04)$ & $0.8(0.1)$ \\
\hline
\end{tabular}




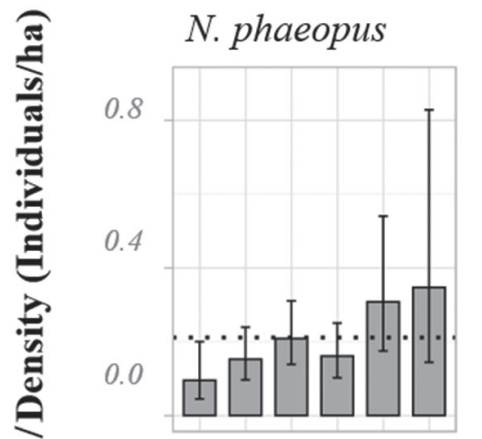

A. macularius

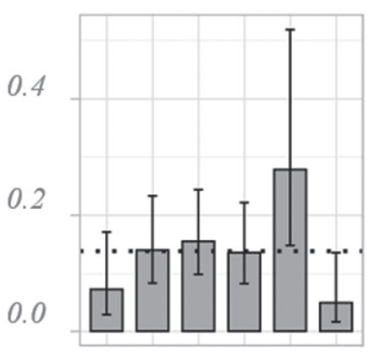

Sl Gu Sn Am Ta Is
T. semipalmata

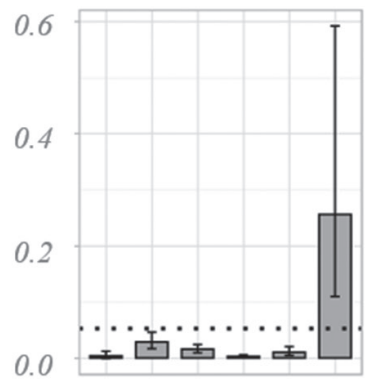

C. mauri/pusilla

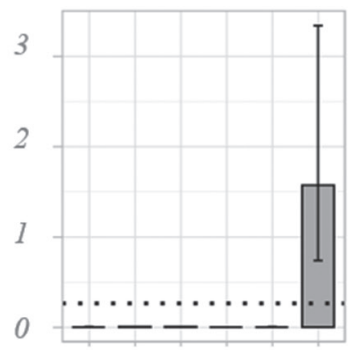

Sl Gu Sn Am Ta Is
T. melanoleuca

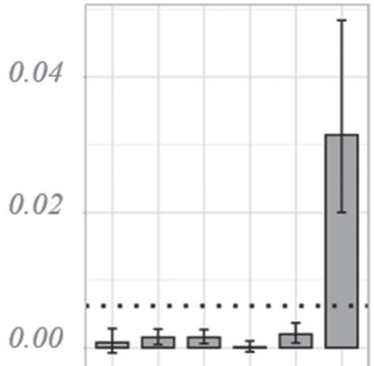

Ch. wilsonia

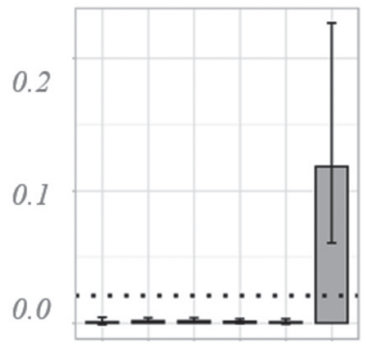

Sl Gu Sn Am Ta Is
P. squatarola

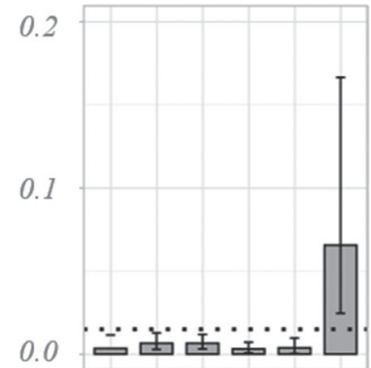

Ch. semipalmatus

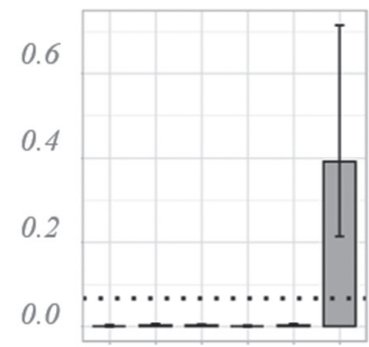

Sl Gu Sn Am Ta Is

\section{Bocana/River mouth}

Figura 6. Variación espacial en la densidad de ocho especies de aves playeras en cinco bocanas del PNNS ( $\mathrm{Sl}=$ Salango, $\mathrm{Gu}=$ Guascama, $\mathrm{Sn}=$ Sanquianga, $\mathrm{Am}=$ Amarales y $\mathrm{Ta}=$ Tapaje) e IS (Iscuandé) . Los puntos representan el promedio de cada bocana y las barras los intervalos de confianza de $95 \%$. La línea punteada y el número debajo de cada especie es el promedio global de densidad para toda el área de estudio
Figure 6. Spatial variation in the density of eight species of shorebirds in five mouths of the SNNP ( $\mathrm{Sl}=$ Salango, $\mathrm{Gu}=$ Guascama, $\mathrm{Sn}=$ Sanquianga, $\mathrm{Am}=$ Amarales, and $\mathrm{Ta}=$ Tapaje) and IS (Iscuandé). The points represent the average of each mouth and the bars the $95 \%$ confidence intervals. The dotted line and the number below each species is the overall average density for the entire study area.
Tabla 2. Promedio y error estándar (SE) en la densidad de ocho especies de aves playeras comunes en cinco bocanas del Parque Nacional Natural Sanquianga $(\mathrm{Sl}=$ Salango, $\mathrm{Gu}=$ Guascama, $\mathrm{Sn}=$ Sanquianga, $\mathrm{Am}=$ Amarales y $\mathrm{Ta}=$ Tapaje) y la bocana de Iscuandé (Is).
Table 2. Average and standard error (SE) of the density of eight species of common shorebirds in five mouths of the Sanquianga National Natural Park $(\mathrm{Sl}=$ Salango, $\mathrm{Gu}=$ Guascama, $\mathrm{Sn}=$ Sanquianga, $\mathrm{Am}=$ Amarales and $\mathrm{Ta}=$ Tapaje) and the mouth of Iscuandé (Is).

\begin{tabular}{|l|c|c|c|c|c|c|}
\hline Spp/Bocana/Spp/mouth & SI & Gu & Sn & Am & Ta & Is \\
\hline N. phaeopus & $0.09(0.04)$ & $0.15(0.04)$ & $0.21(0.04)$ & $0.16(0.04)$ & $0.31(0.09)$ & $0.35(0.15)$ \\
\hline T. semipalmata & $0.05(0.16)$ & $0.29(0.09)$ & $0.12(0.08)$ & $0.03(0.09)$ & $0.1(0.11)$ & $1.37(0.18)$ \\
\hline T. melanoleuca & $0(0.1)$ & $0.01(0.06)$ & $0.01(0.05)$ & $0(0.05)$ & $0.01(0.06)$ & $0.78(0.1)$ \\
\hline $\begin{array}{l}\text { P. squatarola } \\
\text { A. macularius }\end{array}$ & $0.04(5.66)$ & $0.07(3.04)$ & $0.08(2.66)$ & $0.05(2.73)$ & $0.08(3.35)$ & $25.15(5.6)$ \\
\hline C. mauri/pusilla & $0.59(0.24)$ & $0.67(0.15)$ & $0.43(0.13)$ & $0.57(0.15)$ & $0.75(0.19)$ & $0.94(0.29)$ \\
\hline Ch. wilsonia & $0(0)$ & $0(0)$ & $0(0)$ & $0(0)$ & $0(0)$ & $0.02(0.54)$ \\
\hline Ch. semipalmatus & $0.02(0.85)$ & $0.04(0.47)$ & $0.06(0.41)$ & $0.02(0.43)$ & $6.21(0.88)$ \\
\hline
\end{tabular}




\section{DISCUSIÓN}

La conservación de especies migratorias requiere de conjuntos de sitios que puedan ofrecer hábitat para múltiples especies (Senner et al., 2017). 10 años de conteo en dos sitios importantes en el corredor migratorio del Pacífico Americano: el Parque Nacional Natural Sanquianga y la bocana de Iscuandé muestran que, aunque son cuencas contiguas, la composición de aves playeras en estos dos sitios es muy diferente. Seis de ocho especies comunes tuvieron mayor probabilidad de ser registradas y una mayor densidad en Iscuandé, mientras que las dos especies restantes, A. macularius y $N$. phaeopus presentaron mayor probabilidad de presencia y densidad al interior del PNNS. Además del recambio de especies, la abundancia acumulada de individuos de aves playeras mostró un mayor aporte de las aves pequeñas en Iscuandé, principalmente Calidris mauri y C. pusilla. Estos resultados muestran que PNNS y IS ofrecen hábitat para comunidades compuestas por distintas especies y tamaños de aves playeras y que su papel en la conservación de sitios sería complementario.

Otros estudios también han encontrado patrones diferenciales para la distribución espacial de tamaños de este grupo de aves. Por ejemplo, en la bahía de Panamá, las especies del género Calidris tienden a concentrarse en los sectores más externos de la bahía (Kauffman et al., 2018), mientras las aves grandes pueden ocupar áreas más próximas al manglar. Los resultados del presente estudio sugieren que estos patrones de distribución diferencial de especies pequeñas también se cumplen en el norte de Nariño con una distribución más equitativa de aves grandes y pequeñas en PNNS y predominancia de aves pequeñas en IS. Las diferencias en la composición de la comunidad de aves playeras entre PNSS y IS pueden ser ocasionadas por múltiples factores, incluyendo aquellos propios de la historia de vida de especies, que incluyen su tamaño, modo de alimentación, y vulnerabilidad a depredadores (Johnston-González, 2019) y las condiciones de hábitat, en particular el tamaño de los sitios y disponibilidad de recursos en el hábitat (Jiménez, 2013), el riesgo de depredación (Martins et al., 2015; Hope, 2018) y su proximidad al océano (Martínez-Curci et al., 2015). Por ejemplo, durante la migración posreproductiva, Calidris mauri selecciona áreas con menor proximidad a la vegetación (Hope, 2018), algo que se interpreta como la selección de área con menor riesgo de depredación. En este sentido, la predominancia de aves playeras pequeñas en IS podría ser resultado de la selección de localidades grandes, de más de 500 ha, que ofrecen mayor área contigua de hábitat

\section{DISCUSSION}

The conservation of migratory species requires sets of sites that can offer habitat for multiple species (Senner et al., 2017). 10 years of counting at two important sites in the Pacific Americas Flyway: the Sanquianga National Natural Park and the mouth of Iscuandé River show that although they are contiguous basins, the composition of shorebirds in these two sites is very different. Six out of eight common species had a higher probability of being recorded and a higher density in Iscuandé, while the remaining two species, A. macularius and $N$. phaeopus, had a higher probability of presence and density within the SNNP. In addition to species turnover, the accumulated abundance of shorebird individuals showed a greater contribution from small birds in Iscuandé, mainly Calidris mauri and C. pusilla. These results show that SNNP and IS offer habitat for communities composed of different shorebird species and sizes and that their role in site conservation would be complementary.

Other studies have also found differential patterns for the spatial size distribution of this group of birds. For example, in the Bay of Panama, the species of the genus Calidris tend to be concentrated in the outermost sectors of the Bay (Kauffman et al., 2018), while large birds may occupy areas closer to the mangrove. The results of the present study suggest that these patterns of differential distribution of small species are also met in the north of Nariño with a more equitable distribution of large and small birds in SNNP and predominance of small birds in IS. The differences in the composition of the shorebird community between PNSS and IS can be caused by multiple factors, including those specific to the life history of species, including their size, feeding mode, and vulnerability to predators (Johnston-González, 2019) and habitat conditions, in particular the size of the sites and availability of resources in the habitat (Jiménez, 2013), the risk of predation (Martins et al., 2015; Hope, 2018), and its proximity to the ocean (Martínez-Curci et al., 2015). For example, during post-breeding migration, Calidris mauri selects areas with less proximity to vegetation (Hope, 2018), something that is interpreted as selecting the area with the lowest risk of predation. In this sense, the predominance of small shorebirds in IS could be the result of the selection of large localities, of more than $500 \mathrm{ha}$, that offer a greater contiguous area of habitat and concentration of resources in the same place as well as less vulnerability to predators. These conditions may attact the 
y concentración de recursos en un mismo lugar, así como menor vulnerabilidad ante depredadores. Estas condiciones podrían atraer a grandes bandadas de aves como las que forman las especies pequeñas de Calidris.

Aunque no se evaluó cuantitativamente, la mayor proximidad geográfica de los planos intermareales a la línea costera en Iscuandé presentan mayor influencia marina, mientras que al interior del PNN, con localidades hasta $30 \mathrm{~km}$ río arriba presentan una influencia más estuarina e incluso de agua dulce. La influencia del tipo de hábitat y su proximidad al océano es uno de los mayores factores que explican las diferencias en la distribución de aves playeras en otras localidades tropicales (Ribeiro et al., 2004; Martínez-Curci et al., 2015). Aunque escapa el alcance de este estudio, es importante entender los patrones temporales interanuales y multianuales de la comunidad de aves playeras. Sin embargo, la serie de datos analizados en este estudio, muestra una variación natural de la comunidad de aves de la región del norte de Nariño, lo cual puede ser insumo para definir umbrales poblacionales requeridos para evaluar la efectividad de manejo del área protegida (PNN Sanquianga, 2017) o los logros de conservación del acuerdo del manglar (Asociación Calidris y consejo comunitario Esfuerzo Pescador, 2017).

Al interior del PNNS la influencia de la desembocadura del río Patía-Sanquianga, ha causado cambios en la hidrología y la tasa de sedimentación de las bocanas durante más de 30 años (Parra y Restrepo, 2014). Análisis morfológicos muestran que en las bocanas Sanquianga y Guascama se moviliza mayor caudal y sedimentos provenientes del río, y que la intrusión salina en el estuario cada vez es menor debido al avance del río hacia la costa, produciendo alteraciones hídricas y ecosistémicas significativas, mientras que las condiciones de la bocana de Amarales se han mantenido estables en este mismo periodo (Parra y Restrepo, 2014). Los resultados del presente estudio indican un patrón diferencial en la composición taxonómica y por categorías de tamaños de aves playeras en las bocanas con mayor influencia del Patianga. Sin embargo, la predicción sobre diferencias en la distribución y abundancia sectores centro-occidental (Guascama y Sanquianga) no fue apoyada por los datos de probabilidad de presencia y densidad de aves grandes o pequeñas. Una excepción es Tringa semipalmata, la cual presentó una alta ocupación de planos intermareales en las bocanas de Sanquianga y Guascama. De acuerdo con Reiter et al. (2020), esta especie también ha aumentado su distribución en otras áreas del Pacífico americano. flocks of birds such as those formed by the small species of Calidris.

Although it was not quantitatively evaluated, the greater geographic proximity of the tidal flats to the coastline in Iscuandé presents greater marine influence, while within the PNN, with localities up to $30 \mathrm{~km}$ upriver, present a more estuarine and even freshwater influence. The influence of the type of habitat and its proximity to the ocean is one of the major factors that explain the differences in the distribution of shorebirds in other tropical locations (Ribeiro et al., 2004; Martínez-Curci et al., 2015). Although it is beyond the scope of this study, it is important to understand the interannual and multiyear temporal patterns of the shorebird community. However, the series of data analyzed in this study shows a natural variation of the bird community in the northern region of Nariño, which can be an input to define the population thresholds required to evaluate the effectiveness of management of the protected area (PNN Sanquianga, 2017), or the conservation achievements of the Mangrove Agreement (Asociación Calidris and consejo comunitario Esfuerzo Pescador, 2017).

Within the SNNP, the influence of the mouth of the Patía-Sanquianga river has caused changes in the hydrology and sedimentation rate of the mouths for more than 30 years (Parra and Restrepo, 2014). Morphological analyzes show that in the Sanquianga and Guascama mouths greater flow and sediments from the river are mobilized and that the saline intrusion in the estuary is lower due to the advance of the river towards the coast, producing significant hydric and ecosystem alterations, while the conditions of the Amarales mouth have remained stable in this same period (Parra and Restrepo, 2014). The results of the present study indicate a differential pattern in the taxonomic composition and by size categories of shorebirds in the mouths with the greatest influence of the Patianga. However, the prediction of differences in the distribution and abundance of central-western sectors (Guascama and Sanquianga) was not supported by the data on the probability of presence and density of large or small birds. An exception is Tringa semipalmata, which presented a high occupation of tidal flats in the Sanquianga and Guascama mouths. According to Reiter et al. (2020), this species has also increased its distribution in other areas of the American Pacific.

The marine-estuarine gradient can also influence the behavior of shorebird communities. In the case of 
El gradiente marino-estuarino también puede influir en el comportamiento de las comunidades de aves playeras. En el caso del PNNS, este gradiente se extiende a lo largo de $30 \mathrm{~km}$ hacia el continente y puede incluir planos con influencia marina, estuarina o continental. En IS los planos intermareales están ubicados directamente sobre la línea de costa o a pocos kilómetros $(<5 \mathrm{~km})$ de la misma (MADS et al., 2015) por lo que se asumió una mayor influencia marina. Esta influencia podría ocasionar diferencias en la composición de sedimentos, aportes de materia orgánica y, en últimas, diferentes comunidades bentónicas que los habitan y conforman la dieta de aves playeras. En particular, especies del género Calidris, que se alimentan sobre biopelículas (Kuwae et al., 2012), un recurso de distribución localizada, que es un factor limitante para la distribución de las especies.

La complementariedad de las áreas muestra un gradiente de tamaños en sitios de alimentación, cercanía a parches de manglar y a poblados, entre otros, lo cual podría aportar un gradiente útil a estudios sobre los factores que condicionan el comportamiento de la composición y la distribución temporal y espacial de esta comunidad de aves. Entre estos factores se ha estudiado el efecto de la proximidad a vegetación o barreras que puedan obstruir la vigilancia de los alrededores (Ydenberg et al., 2002; Pomeroy et al., 2008; Martins et al., 2015) y el comportamiento diferencial que presentan las especies según sus categorías de tamaño. Otro de los aspectos interesantes para próximos estudios es el uso que se le da a los sitios en diferentes escalas temporales, como a lo largo de un día o en las etapas del ciclo migratorio o reproductivo de las aves playeras (Cifuentes-Sarmiento y Ruiz-Guerra, 2009).

\section{CONCLUSIONES}

En este estudio se documenta la variación espacial de la abundancia de aves playeras durante 10 años $(2009,2012-$ 2020) en planos intermareales en el extenso paisaje costero de $1000 \mathrm{~km}^{2}$ del norte de Nariño, Colombia. La composición y abundancia de aves playeras fue muy diferente entre IS y PNNS, lo que indica la complementariedad de estos sitios para la conservación del hábitat. En los planos costeros y más marinos de IS, las aves pequeñas contribuyeron con más de $80 \%$ de la abundancia, con C. mauri-pusilla dominando numéricamente. En los planos pequeños y rodeados de manglar a lo largo del gradiente estuarino de PNNS, la abundancia se repartió de manera más equitativa entre especies pequeñas y grandes, al ser A. macularia (pequeña) y $N$. phaeopus (grande) las especies más frecuentes y abundantes. Estas diferencias the SNNP, this gradient extends for $30 \mathrm{~km}$ towards the continent and can include planes with a marine, estuarine or continental influence. In IS, the tidal flats are located directly on the coastline or a few kilometers $(<5 \mathrm{~km})$ from it (MADS et al., 2015), for which a greater marine influence was assumed. This influence could cause differences in the composition of sediments, contributions of organic matter, and ultimately, different benthic communities that inhabit them and make up the diet of shorebirds. In particular, species of the genus Calidris spp. that feed on biofilms (Kuwae et al., 2012), a localized distribution resource, which is a limiting factor for the distribution of species.

The complementarity of the areas shows a size gradient in feeding sites, proximity to mangrove patches, and to towns, among others, which could provide a useful gradient for studies on the factors that condition the behavior of the composition and temporal distribution and space of this community of birds. Among these factors, the effect of proximity to vegetation or barriers that may obstruct surveillance of the surroundings (Ydenberg et al., 2002; Pomeroy et al., 2008; Martins et al., 2015) and the differential response of species according to their size categories. Another interesting aspect for future studies is the use that is given to the sites in different temporal scales, such as throughout a day or in the stages of the migratory or reproductive cycle of shorebirds (CifuentesSarmiento and Ruiz-Guerra, 2009).

\section{CONCLUSIONS}

This study documents the spatial variation of shorebird abundance over 10 years (2009, 2012-2020) in tidal flats in the extensive $1000 \mathrm{~km}^{2}$ coastal landscape of northern Nariño, Colombia. The composition and abundance of shorebirds were very different between IS and PNNS, indicating the complementarity of these sites for habitat conservation. In the coastal and more marine planes of IS, small birds contributed more than $80 \%$ of the abundance, with C. mauri-pusilla dominating numerically. In the small planes surrounded by mangroves along the estuarine gradient of PNNS, abundance was distributed more evenly between small and large species, with $A$. macularia (small) and $N$. phaeopus (large) being the most frequent species and abundant. These differences on a regional scale could be explained by variations in the size and configuration of tidal flats, differences in the marine gradient and in food resources, as well as differences in the natural history of the species, factors that require further 
a escala regional podrían explicarse por variaciones en el tamaño y configuración de planos intermareales, diferencias en el gradiente marino y en recursos alimenticios, así como por diferencias en la historia natural de las especies, factores que requieren mayor investigación. Estos resultados contribuyen al establecimiento de la línea base sobre la variabilidad espacial de la abundancia de aves playeras, que puede usarse para el seguimiento de valores objeto de conservación como los planos intermareales al interior del Parque Nacional Natural Sanquianga y la bocana de Iscuandé. Al ser parte de un monitoreo coordinado a escala hemisférica, los conteos del norte de Nariño también contribuyen al conocimiento del estado de las poblaciones de este grupo de aves en la ruta del Pacífico americano.

\section{AGRADECIMIENTOS}

A los jefes y funcionarios del Parque Nacional Natural Sanquianga, con quienes se trabajó en el ajuste del protocolo de monitoreo y que permitieron las salidas de campo, en especial a los jefes Nianza Angulo, José Arvey Loaiza y Gustavo Mayor; a los funcionarios Leidy Diana Cifuentes, Edinson Anchico, Edwin Caicedo, Yerson Manuel Caicedo Anchico, Paula Casas Cortés, Darly Xiomara Estupiñán Payán, Diego Estupiñán, Julio Grueso Anchico, Wilfrido Ibarbo Biojó, Saturnino Montaño Solís, Víctor Hugo Estupiñán, Janner Rodríguez y Eder Torres de la Cruz, y a los representantes y comunidades de los consejos comunitarios asentados en el PNN Sanquianga. En la Dirección Territorial Pacífico, a José Luis García, Andrés Cuellar y Paula Giraldo. Al consejo comunitario Esfuerzo Pescador y sus representantes, en especial a Carlos Congolino, Wilmer Estupiñán, Ember Anchico, Carmelo Castillo y Jacinta Congolino. Al equipo de la Asociación Calidris, en especial a Fernando Castillo, Carlos Ruiz, Yanira Cifuentes, César Arango, Pedro Camargo, Jeisson Zamudio, Marlyn Zuluaga, Dina Estupiñán, Felipe Estela, Karolina Fierro, Eliana Fierro, Fernando Ortega y Alexander González por su apoyo en el trabajo de campo y la discusión de protocolos y de resultados. A la iniciativa Crimbi y sus socios y al proyecto de las aves playeras migratorias, su comité coordinador y sus socios, en especial a Matt Reiter y Catherine Hickey de Point Blue Conservation Science, a Eduardo Palacios del Centro de Investigación Científica y de Educación Superior de Ensenada y a Rob Clay de la oficina ejecutiva de la Red Hemisférica de Aves Playeras de Manomet. Durante la recolección y el análisis de información, RJG contó con el apoyo del Centro para la investigation. These results contribute to establishing the baseline on the spatial variability of shorebird abundance that can be used to monitor conservation target values such as tidal flats within the Sanquianga National Natural Park and mouth of Iscuandé. As part of coordinated monitoring on a hemispheric scale, the counts from the north of Nariño also contribute to the knowledge of the status of the populations of this group of birds on the American Pacific flyway.

\section{ACKNOWLEDGEMENTS}

To the chiefs and officials of the Sanquianga National Natural Park who worked on adjusting the monitoring protocol and allowed field trips, especially chiefs Nianza Angulo, José Arvey Loaiza and Gustavo Mayor; officials Leidy Diana Cifuentes, Edinson Anchico, Edwin Caicedo, Yerson Manuel Caicedo Anchico, Paula Casas Cortés, Darly Xiomara Estupiñán Payán, Diego Estupiñán, Julio Grueso Anchico, Wilfrido Ibarbo Biojó, Saturnino Montaño Solís, Víctor Hugo Estupiñán, Janner Rodríguez and Eder Torres de la Cruz, and the representatives and communities of the Community Councils that settled in the PNN Sanquianga. In the Pacific Territorial Directorate, José Luis García, Andrés Cuéllar and Paula Giraldo. To the Esfuerzo Pescador Community Council and its representatives, especially Carlos Congolino, Wilmer Estupiñán, Ember Anchico, Carmelo Castillo, and Jacinta Congolino. To the team of the Calidris Association, especially Fernando Castillo, Carlos Ruiz, Yanira Cifuentes, César Arango, Pedro Camargo, Jeisson Zamudio, Marlyn Zuluaga, Dina Estupiñán, Felipe Estela, Karolina Fierro, Eliana Fierro, Fernando Ortega, and Alexander González for their support in the field work and the discussion of protocols and results. To the Crimbi initiative and its partners and the Migratory Shorebirds Project, its coordinating committee and its partners, especially Matt Reiter and Catherine Hickey of Point Blue Conservation Science, Eduardo Palacios of the Ensenada Center for Scientific Research and Higher Education and to Rob Clay from the executive office of the Manomet Hemispheric Shorebird Network. During the collection and analysis of information, RJG had the support of the Center for Ecology and Wildlife (CWE) of Simon Fraser University (SFU), the Environment and Climate Change Service of Canada (ECC), the scholarship program of Coastal Solutions (CSF) of the Cornell Laboratory of Ornithology and the GEO program of Invemar. To the 
Ecología y Vida Silvestre (CWE) de la Universidad Simon Fraser (SFU), el Servicio del Ambiente y Cambio Climático de Canadá (ECC), el programa de becarios de Soluciones Costeras (CSF) del Laboratorio de Ornitología Cornell y el programa GEO del Invemar. Al Servicio Forestal y al Servicio de Pesca y Vida Silvestre de los Estados Unidos por apoyar el trabajo de campo. Contribución 1288 del Invemar.
Forest Service and the US Fish and Wildlife Service for supporting the fieldwork. Contribution 1288 of Invemar.

\section{BIBLIOGRAFÍA/LITERATURE CITED}

Alonso, D., L. Ramírez, C. Segura-Quintero, P. Castillo-Torres, J.M. Díaz y T. Walschburger. 2008. Prioridades de conservación in situ para la biodiversidad marina y costera de la plataforma continental del Caribe y Pacífico colombiano. Instituto de Investigaciones Marinas y Costeras, The Nature Conservancy y Unidad Administrativa de Parques Nacionales, Santa Marta. 20 p.

Asociación Calidris. 2009. Aves marinas y playeras en el PNN Sanquianga y la bocana de Iscuandé entre 2007 y 2009 , 1737 registros, aportados por Zamudio, J. (creador del recurso). http://ipt.sibcolombia.net/valle/archive.do?r=aves_pnnsanquianga_iscuande. 04/06/2013.

Asociación Calidris y consejo comunitario Esfuerzo Pescador. 2017. La bocana de Iscuandé, un lugar que conservamos. Resultados del monitoreo participativo en el territorio colectivo del consejo comunitario Esfuerzo Pescador. Asociación Calidris, Cali. 36 p.

Asociación Calidris y PNN Sanquianga. Datos inéditos. Monitoreo de aves playeras en los planos lodosos del PNN Sanquianga 2011-2020. SULA. Parques Naturales Nacionales de Colombia.

Butler, R.W., R.C. Ydenberg, G.D. Donaldson, and S. Brown. 2004. Hypotheses to explain census declines in North American shorebirds. Shorebird Research Group of the Americas, Report 1. http://www.shorebirdresearch.org/workinggroups.htm. 01/10/2017.

Calderón-Leytón, J.J., C. Flórez Paí, A. Cabrera-Finley e Y. Rosero Mora. 2011. Aves del departamento de Nariño, Colombia. Biota Colomb., 12(1): 31-116. https://www.redalyc.org/articulo.oa?id=49122290003

Cifuentes-Sarmiento, Y. y C.J Ruiz-Guerra (Eds.). 2009. Planes de acción para nueve especies de aves acuáticas (marinas y playeras) de las costas colombianas. Asociación Calidris, Cali. 100 p.

Fick, S.E. and R.J. Hijmans. 2017. WorldClim 2: new 1-km spatial resolution climate surfaces for global land areas. Int. J. Climatol, 37(12): 4302-4315. https://doi.org/10.1002/joc.5086

Fundación Natura e Invemar. 2019. Servicios ecosistémicos marinos y costeros de Colombia: énfasis en manglares y pastos marinos. Contrato de subvención n. ${ }^{\circ}$ EU ENV/2016/380-526. Santa Marta, Colombia.

Hope, D.D. 2018. The role of adaptive behaviour in migratory counts of shorebirds. Ph.D. Thesis. Simon Fraser Univ., Vancouver. 310 p.

IDEAM. 2016. Pronóstico de pleamares y bajamares en la costa Pacífica colombiana año 2017. Instituto de Hidrología, Meteorología y Estudios Ambientales, Bogotá, D.C. 132 p.

IDEAM, IGAC, IAvH, Invemar, I. Sinchi, IIAP. 2007. Ecosistemas continentales, costeros y marinos de Colombia. Imprenta Nacional de Colombia, Bogotá. 276 p. +37 hojas cartográficas.

Jiménez, A. 2013. The "secret garden”: microphytobenthic biofilms and the foraging ecology of Calidridine sandpipers. Ph.D. Thesis, Simon Fraser Univ., Burnaby, Canadá. 158 p.

Johnston-González, R. 2019. The influence of predation danger on the distribution of non-breeding shorebirds in a tropical estuary system. Ph.D. Thesis, Simon Fraser Univ., Burnaby, Canadá. 133 p.

Johnston-González, R. y D. Eusse-González. 2009a. Sitios importantes para la conservación de las aves playeras en Colombia. Asociación Calidris, Cali. $34 \mathrm{p}$.

Johnston-González, R. y D. Eusse-González. 2009b. Sitios importantes para la conservación de las aves playeras en Colombia. Informe Técnico. Asociación Calidris, Cali. 83 p. http://calidris.org.co/wp-content/uploads/2009/09/SitiosImportantes_Tecnico.pdf

Johnston-González, R., C.J. Ruiz-Guerra, D. Eusse-González, L.F. Castillo-Cortés, Y. Cifuentes-Sarmiento, P. Falk-Fernández y V. Ramírez De Los Ríos. 2010. Plan de conservación para aves playeras en Colombia. Asociación Calidris, Cali. 44 p.

Kuwae, T., E. Miyoshi, S. Hosokawa, K. Ichimi, J. Hosoya, T. Amano, T. Moriya, M. Kondoh, R.C. Ydenberg, and R.W. Elner 2012. Variable and complex food web structures revealed by exploring missing trophic links between birds and biofilm. Ecol. Lett., 15: 347-356. https://doi.org/10.1111/j.14610248.2012.01744.x 
Lank, D.B., R.W. Butler, J. Ireland, and R.C. Ydenberg. 2003. Effects of predation danger on migration strategies of sandpipers. Oikos, $103(2)$ : 303-319.

Lenth, R. 2016. Least-Squares means: The R package lsmeans. J Stat Softw, 69(1): 1-33. doi:10.18637/jss.v069.i01

MADS, IDEAM, IAVH, SINCHI, INVEMAR, IIAP, PNN e IGAC. 2015. Mapa de ecosistemas continentales, costeros y marinos de Colombia, escala 1:100.000. Convenio marco n. ${ }^{\circ} 4206$ de 2011 MADS (Issue 4206).

Martínez-Curci, N.S., I.P. Isacch, and A.B. Azpiroz. 2015. Shorebird seasonal abundance and habitat-use patterns in Punta Rasa, Samborombón Bay, Argentina. Waterbirds, 38(1): 68-76. https://doi.org/10.1675/063.038.0109

Martins, R.C., T. Catry, R. Rebelo, S. Pardal, S.J.M. Palmeirim, and J.P. Granadeiro. 2015. Contrasting estuary-scale distribution of wintering and migrating waders: the potential role of fear. Hydrobiologia, 768: 211-222. https://doi.org/10.1007/s10750-015-2549-x

Murray, N.J., S.R. Phinn, M. DeWitt, R. Ferrari, R. Johnston, M.B. Lyons, N. Clinton, D. Thau, and R.A. Fuller. 2019. The global distribution and trajectory of tidal flats. Nature, 565: 222-225. https://doi.org/10.1038/s41586-018-0805-8

Parra, A.S. y J.D. Restrepo. 2014. El colapso ambiental en el río Patía, Colombia: variaciones morfológicas y alteraciones en los ecosistemas de manglar. Lat. Am. J. Aquat. Res., 42(1): 40-60. http://dx.doi.org/103856/vol42-issue1-fulltext-4

Pomeroy, A.C., D.A.A Seaman, R.W. Butler, R.W. Elner, T.D. Williams and R.C. Ydenberg. 2008. Feeding-danger trade-offs underlie stopover site selection by migrants. Avian Cons. Ecol., 3(1): 7. http://www.ace-eco.org/vol3/iss1/art7/

Posada, B.O., W. Henao y G. Guzmán. 2009. Diagnóstico de la erosión y sedimentación en la zona costera del Pacífico colombiano. Ser. Publ. Espec. Invemar, (17), Santa Marta. 148 p.

Pyle, P. 2008. Identification guide to North American birds. Part II: Anatidae to Alcidae. Slate Creek Press, Point Reyes Station, California. 836 p.

R Core Team. 2020. R: A language and environment for statistical computing. R Foundation for Statistical Computing, Vienna. https://www.R-project.org/

Reiter, M.E., E. Palacios, D. Eusse-Gonzalez, R. Johnston González, P. Davidson, D.W. Bradley, R. Clay, K.M. Strum, J. Chu, B.A. Barbaree, C.M. Hickey, D.B. Lank, M. Drever, R.C. Ydenberg, and R. Butler. 2020. A monitoring framework for assessing threats to non-breeding shorebirds on the Pacific Coast of the Americas. Avian Conserv. Ecol., 15(2): 7. http://www.ace-eco.org/vol15/iss2/art7/

Restrepo, J.D. and J. Cantera. 2011. Discharge diversion in the Patía River delta, the Colombian Pacific: geomorphic and ecological consequences for mangrove ecosystems. J South Am Earth Sci, 46: 183-198. https://doi.org/10.1016/j.jsames.2011.04.006

Restrepo, J.D. and A. Kettner. 2012. Human induced discharge diversion in a tropical delta and its environmental implications: The Patía River, Colombia. J. Hydrol., 424-425: 124-142. https://doi.org/10.1016/j.jhydrol.2011.12.037

Ribeiro, P.D., O.O. Iribarne, Navarro, and L. Jaureguy. 2004. Environmental heterogeneity, spatial segregation of prey, and the utilization of southwest Atlantic mudflats by migratory shorebirds. Ibis, 146(4): 672-682.

Ruiz-Guerra, C. 2011. Avifauna del complejo marino costero Iscuandé Sanquianga Gorgona (CISG). Calidris, Cali. http://dx.doi.org/10.13140/2.1.1234.0007

Ruiz-Guerra, C. 2013. Lista de las aves acuáticas de Colombia, 284 registros. http://ipt.sibcolombia.net/valle/resource.do?=aves_acuaticas_colombia. $25 / 10 / 2013$

Ruiz-Guerra, C., R. Johnston-González, Y. Cifuentes-Sarmiento, F. Estela, L.F. Castillo, C.E. Hernández-Corredor, and L.G. Naranjo. 2007. Noteworthy bird records from the southern Chocó of Colombia. Bull. B.O.C., 127: 283-293.

Senner, S.E., B.A. Andres y H.R. Gates (Eds.). 2017. Estrategia de conservación de las aves playeras de la ruta del Pacífico de Las Américas. National Audubon Society, Nueva York. https://www.shorebirdplan.org/wp-content/uploads/2017/03/Pacific-Americas-Strategy-2016.pdf

Thomas, G. H., R.B. Lanctot, and T. Szekely. 2006. Can intrinsic factors explain population declines in North American breeding shorebirds? A comparative analysis. Anim. Conserv., 9(3): 252-258. https://doi.org/10.1111/j.1469-1795.2006.00029.x

von Prahl, H., J. Cantera. y R. Contreras R. 1990. Manglares y hombres en el Pacífico colombiano. FEN, Bogotá. 198 p.

Ydenberg, R.C., R.W. Butler, D.B. Lank, C.G. Guglielmo, M. Lemon, and N. Wolf. 2002. Trade-offs, condition dependence and stopover site selection by migrating sandpipers. J. Avian Biol., 33(1): 47-55.

Zamudio, J., R. Johnston y D. Eusse. 2013. Censo del zarapito trinador (Numenius phaeopus) y otras aves acuáticas en el Parque Nacional Natural Sanquianga. http://ipt.sibcolombia.net/valle/archive.do?r=censo_numenius_phaeopus_2009. 31/07/2013. 


\section{ANEXOS/APPENDICES}

Anexo 1. Número de localidades visitadas (N), área cubierta (ha), número de registros e individuos contados (abundancia) en 10 años de conteo de aves playeras del norte de Nariño (Colombia).
Appendix 1. Number of localities visited (N), the area covered (ha), number of records, and counted individuals (abundance) in 10 years of counting shorebirds from the north of Nariño (Colombia).

\begin{tabular}{|c|c|c|c|c|}
\hline Año/Year & Localidades/Localities & Área & Registros/Records & Abundancia/Abundance \\
\hline 2009 & 62 & 3715 & 172 & 981 \\
\hline 2012 & 83 & 2654 & 228 & 34382 \\
\hline 2013 & 58 & 2485 & 199 & 31651 \\
\hline 2014 & 96 & 4258 & 360 & 22230 \\
\hline 2015 & 67 & 2428 & 150 & 9317 \\
\hline 2016 & 86 & 5435 & 283 & 9287 \\
\hline 2017 & 80 & 3874 & 302 & 8280 \\
\hline 2018 & 80 & 3747 & 277 & 2900 \\
\hline 2019 & 83 & 4921 & 296 & 7639 \\
\hline 2020 & 65 & 3737 & 276 & 5753 \\
\hline Promedio/Average & 76 & 3725.4 & 254.3 & 13242 \\
\hline
\end{tabular}

Anexo 2. Frecuencia y abundancia máxima de especies comunes de aves playeras grandes $(>100 \mathrm{~g})$ y pequeñas $(<100 \mathrm{~g})$ entre 2009 y 2020 en 162 planos intermareales del norte de Nariño (Colombia). El número total de registros es de 2943 (95 registros corresponden a categorías agrupadas y a especies poco comunes). En cuatro localidades no se obtuvieron registros de aves o no se identificó el grupo.
Appendix 2. Frequency and maximum abundance of common large $(>100$ g) and small $(<100 \mathrm{~g})$ shorebird species between 2009 and 2020 in 162 tidal flats of northern Nariño (Colombia). The total number of records is 2943 (95 records correspond to grouped categories and rare species). In four localities we did not have bird records or did not identify the group.

\begin{tabular}{|c|c|c|c|c|}
\hline Taxón & Años/Years & $\begin{array}{l}\text { Localidades con registros de aves/ } \\
\text { Locations with bird records (\%) }\end{array}$ & Registros/Records (\%) & Total anual (\%) \\
\hline Charadriidae & & $86(55)$ & $485(16)$ & 7709 (19) \\
\hline \multicolumn{5}{|l|}{ Grande/Large } \\
\hline Pluvialis squatarola & 10 & $74(46)$ & $227(8)$ & $5584(13)$ \\
\hline Pequeña/Small & & $61(38)$ & $258(9)$ & $2366(6)$ \\
\hline Charadrius semipalmatus & 10 & $57(35)$ & $142(5)$ & $2107(5)$ \\
\hline Charadrius wilsonia & 10 & $38(23)$ & $116(4)$ & $1735(4)$ \\
\hline \multicolumn{5}{|l|}{ Haematopodidae } \\
\hline \multicolumn{5}{|l|}{ Grande/Large } \\
\hline Haematopus palliatus & 9 & $4(2)$ & $25(1)$ & $30(0)$ \\
\hline
\end{tabular}




\begin{tabular}{|c|c|c|c|c|}
\hline Taxón & Años/Years & $\begin{array}{l}\text { Localidades con registros de aves/ } \\
\text { Locations with bird records (\%) }\end{array}$ & Registros/Records (\%) & Total anual (\%) \\
\hline Scolopacidae & 10 & $158(100)$ & $2338(79)$ & $33628(81)$ \\
\hline Grande/Large & 10 & $155(96)$ & $1363(46)$ & $3564(9)$ \\
\hline Arenaria interpres & 10 & $26(16)$ & $72(2)$ & $158(0)$ \\
\hline Calidris canutus & 6 & $3(2)$ & $12(0)$ & $28(0)$ \\
\hline Limnodromus griseus & 10 & $20(12)$ & $60(2)$ & $2346(6)$ \\
\hline Numenius phaeopus & 10 & $154(95)$ & $776(26)$ & $1488(4)$ \\
\hline Tringa melanoleuca & 10 & $49(30)$ & $104(4)$ & $124(0)$ \\
\hline Tringa semipalmata & 10 & $97(60)$ & $339(12)$ & $526(1)$ \\
\hline Pequeña/Small & 10 & $155(96)$ & $975(33)$ & $31720(77)$ \\
\hline Actitis macularius & 10 & $154(95)$ & $679(23)$ & $1230(3)$ \\
\hline Calidris alba & 10 & $15(9)$ & $44(1)$ & $166(0)$ \\
\hline Calidris mauri & 10 & $50(31)$ & $142(5)$ & $22137(54)$ \\
\hline Calidris minutilla & 9 & $21(13)$ & $33(1)$ & $77(0)$ \\
\hline Calidris pusilla & 8 & $19(12)$ & $44(1)$ & $9160(22)$ \\
\hline Tringa flavipes & 9 & $20(12)$ & $33(1)$ & $78(0)$ \\
\hline Total general/Grand total & & $158(100)$ & $2848(97)$ & $41367(100)$ \\
\hline
\end{tabular}

Anexo 3. Porcentajes por año de individuos totales y área total para cada año por localidad.

\begin{tabular}{|c|c|c|c|c|c|c|}
\hline Año/Year & Salango & Guascama & Sanquianga & Amarales & Tapaje & Iscuandé \\
\hline \multicolumn{7}{|c|}{ A. Individuos totales (\% por año)/Total individuals (\% per year) } \\
\hline 2009 & $32(3.3)$ & $527(53.7)$ & $176(17.9)$ & $124(12.6)$ & $122(12.4)$ & $0(0)$ \\
\hline 2012 & $46(0.1)$ & $364(1.1)$ & $379(1.1)$ & $192(0.6)$ & $203(0.6)$ & $33198(96.6)$ \\
\hline 2013 & $52(0.2)$ & $359(1.1)$ & $730(2.3)$ & $157(0.5)$ & $138(0.4)$ & $30215(95.5)$ \\
\hline 2014 & $64(0.3)$ & $1462(6.6)$ & $1464(6.6)$ & $162(0.7)$ & 374 (1.7) & $18704(84.1)$ \\
\hline 2015 & $9(0.1)$ & 154 (1.7) & $289(3.1)$ & $67(0.7)$ & 147 (1.6) & 8651 (92.9) \\
\hline 2016 & $40(0.4)$ & $5016(54)$ & $1257(13.5)$ & $115(1.2)$ & $317(3.4)$ & $2542(27.4)$ \\
\hline 2017 & $122(1.5)$ & $1227(14.8)$ & $1290(15.6)$ & $250(3)$ & $293(3.5)$ & 5098 (61.6) \\
\hline 2018 & $0(0)$ & $487(16.8)$ & $536(18.5)$ & $254(8.8)$ & $310(10.7)$ & $1313(45.3)$ \\
\hline
\end{tabular}

Appendix 3. Percentages per year of total individuals and total area for each year by location. 


\begin{tabular}{|c|c|c|c|c|c|c|}
\hline Año/Year & Salango & Guascama & Sanquianga & Amarales & Tapaje & Iscuandé \\
\hline 2019 & $0(0)$ & $777(10.2)$ & $1287(16.8)$ & $253(3.3)$ & $359(4.7)$ & $4963(65)$ \\
\hline 2020 & $33(0.6)$ & $1067(18.5)$ & $931(16.2)$ & $213(3.7)$ & $214(3.7)$ & $3295(57.3)$ \\
\hline \multirow{2}{*}{$\begin{array}{l}\text { Promedios/ } \\
\text { Averages }\end{array}$} & 0.7 & 17.9 & 11.2 & 3.5 & 4.3 & 62.6 \\
\hline & 1.03 & 20.03 & 7.05 & 4.08 & 4.10 & 31.82 \\
\hline SE & 0.33 & 6.33 & 2.23 & 1.29 & 1.30 & 10.06 \\
\hline \multicolumn{7}{|c|}{ B. Área total (\% por año)/Total area (\% per year) } \\
\hline 2009 & $236(6.4)$ & $2293(61.7)$ & $618(16.6)$ & $291(7.8)$ & $277(7.5)$ & $0(0)$ \\
\hline 2012 & $224(8.4)$ & $975(36.7)$ & $599(22.6)$ & $481(18.1)$ & 343 (12.9) & $32(1.2)$ \\
\hline 2013 & $226(9.1)$ & $790(31.8)$ & $860(34.6)$ & 307 (12.4) & $276(11.1)$ & $26(1)$ \\
\hline 2014 & $271(6.4)$ & $2135(50.1)$ & $1282(30.1)$ & $313(7.4)$ & $231(5.4)$ & $26(0.6)$ \\
\hline 2015 & $2(0.1)$ & 309 (12.7) & $986(40.6)$ & $502(20.7)$ & $362(14.9)$ & 267 (11) \\
\hline 2016 & $258(4.7)$ & $3361(61.8)$ & $931(17.1)$ & $456(8.4)$ & $353(6.5)$ & $76(1.4)$ \\
\hline 2017 & $215(5.5)$ & $1956(50.5)$ & $871(22.5)$ & $378(9.8)$ & $330(8.5)$ & $124(3.2)$ \\
\hline 2018 & $0(0)$ & 1709 (45.6) & 877 (23.4) & $586(15.6)$ & $361(9.6)$ & $214(5.7)$ \\
\hline 2019 & $169(3.4)$ & $2536(51.5)$ & $1118(22.7)$ & $622(12.6)$ & $303(6.2)$ & $173(3.5)$ \\
\hline 2020 & $16(0.4)$ & $1913(51.2)$ & $853(22.8)$ & $480(12.8)$ & $250(6.7)$ & $225(6)$ \\
\hline \multirow{2}{*}{$\begin{array}{l}\text { Promedios/ } \\
\text { Averages }\end{array}$} & 4.4 & 45.4 & 25.3 & 12.6 & 8.9 & 3.4 \\
\hline & 3.37 & 14.85 & 7.59 & 4.48 & 3.15 & 3.40 \\
\hline SE & 1.07 & 4.69 & 2.40 & 1.42 & 1.00 & 1.07 \\
\hline
\end{tabular}

